\title{
Amorium, Yukarı Şehir İç Sur Alanı Kazısından Geç Ortaçağ Sırlı Seramikleri Üzerine ilk Gözlemler
}

\author{
First Observations on the Glazed Pottery of the Late Medieval Period From the \\ Excavation Internal Wall of Upper City at Amorium
}

\section{Lale Doğer* $\odot$, Muhsine Eda Armağan ${ }^{* *} \oplus$}

\section{Öz}

Çalışmanın konusunu, Doğu Frigya'da yer alan Amorium'un 2017-2018 yılı kazılarında ele geçen sırlı seramikler oluşturmaktadır. Aralarında sırsız seramiklerin de yer aldığı buluntular, Yukarı Şehir İç Sur (iS) alanındaki açma ve sondajlardan, az sayıda da yüzeyden ele geçmişlerdir.

Genelde çok küçük parçalar hâlindeki buluntular, açmalardan birbirlerine yakın seviyelerden çıkarılmıştır. Bu nedenle çalışma metodu olarak her bir açmanın ayrı ayrı buluntu dökümü yerine toplam üzerinden mal gruplarının tanınması tercih edilmiştir. Ancak hazırlanan tablolardaki buluntuların açma yerleri farklı olsa da kot seviyeleri kabul edilebilir değerde birbirine yakındır.

Günlük yaşamda kullanılan yemek servis kapları, mutfakla ilişkili açık ve kapalı saklama kaplarına ait parçalar kırmızı hamurludur. Korunmuş kısımlarından hareketle buluntular "Tek Renk Sırlı Bezemesiz Seramikler”, "Tek Renk Sırlı Sgraffito Seramikler", “Astar Bezemeli Seramikler”, "Çok Renkli Sgraffito” seramiklerin alt grubu Yeşil ve Erguvan Lekeli Kaplar olarak gruplandırılmışlardır. Buluntu yoğunluğu tek renk şeffaf yeşil sırlı kaplara ait olup en azını turkuaz renkliler oluşturmaktadır. "Milet Tipi" olarak tanınan seramiklere ait birleşen birkaç parça mevcuttur.

Bu çalışmada ele alınan buluntularda beliren seramik gruplarının hamur yapısı olarak benzer olanlarının form bakımından da kendi içinde tutarlı olduğu izlenmektedir. Form olarak Amorium Yukarı Şehir, Karacahisar Kalesi ve civarı, Aphrodisias, Ephesos buluntuları ile de yakınlık gözlenmektedir. Bezemeli buluntularda teknik, kompozisyonlar yukarıda adı geçen yerlerdeki buluntularla ortak bir beğeniyi işaret ederken ayrıntıda çeşitlenmektedir ve böylece buluntular 14. yüzyılın ortası-15. yüzyıl başına tarihlendirilebilir. Amorium buluntusu Milet Tipi kâse için de benzerleri gibi şimdilik 14. yüzyıl ortası-15. yüzyı önerilebilir. Ele geçen seramiklerin üretim yerleri konusunda daha ayrıntılı analizler gerekmekle birlikte, Amorium ve yakın coğrafyasının hem hammadde hem de gelenek olarak üretici olma potansiyeli yüksektir.

Anahtar Kelimeler

Frigya Bölgesi, Geç Ortaçağ, Amorium, Sırlı seramik

\section{Abstract}

The subject of the study consists of glazed pottery discovered from 2017-2018 excavations in Amorium, located in East Phrygia. The finds which also include non-glazed pottery were discovered from trenches and drillings and a few from the surface within the Interior Wall (IW) area of the upper city.

* Sorumlu Yazar: Lale Doğer (Doç. Dr.), Ege Üniversitesi, Edebiyat Fakültesi, Sanat Tarihi Bölümü, İzmir, Türkiye. E-posta: lale.doger@ege.edu.tr ORCID: 0000-0002-2235-2408

** Muhsine Eda Armağan (Dr. Öğr. Üyesi), Süleyman Demirel Üniversitesi, Fen-Edebiyat Fakültesi, Sanat Tarihi Bölümü, Isparta, Türkiye. E-posta: muhsinearmagan@sdu.edu.tr ORCID: 0000-0002-6208-7995

Atıf: Doger, Lale ve Armagan, Muhsine Eda. “Amorium, Yukarı Şehir İç Sur Alanı Kazısından Geç Ortaçağ Sırlı Seramikleri Üzerine İlk Gözlemler." Art-Sanat, 14(2020): 71-110. https://doi.org/10.26650/artsanat.2020.14.0004 
Finds are generally small fragments derived from close levels in trenches. Therefore, the study method was to define the item groups via total finds, instead of a separate inventory for each find. Nevertheless, the elevation levels of the finds shown by the tables are close to allowable scale although the trench locations were different.

Food serving items of daily life and fragments of kitchen related storage bowls with or without lids were made of red fabric. Finds were classified as Monochrome Glazed Pottery, Monochrome Sgraffito Pottery, Slip Painted Pottery, Green and Purple Flecked Pottery which is a subgroup of Polychrome Sgraffito pottery with reference to their preserved parts. Most of the finds belonged to monochrome green glazed pottery and the turquoise coloured were the least. There were some congregating fragments which belonged to Miletus Type pottery.

The pottery groups examined in our study were consistent in terms of their forms. They were also analogous with Amorium upper city, Karacahisar Castle and the nearby Aphrodisias and Ephesos finds. While the technique and compositions of decorated finds represented a common taste with the finds of the above-mentioned areas, they differed in details. Finds from the Begliks Period dated from the middle $14^{\text {th }}$ - early $15^{\text {th }}$ centuries. For the Miletus Type bowl found in Amorium, like its counterparts, dated probably from the middle $14^{\text {th }}-15^{\text {th }}$ centuries. Though more detailed analyses are necessary regarding the place of production for pottery finds, Amorium and the nearby area was potentially the place of production according to both raw material and tradition.

\section{Keywords}

Phrygia, Late Medieval, Amorium, Glazed pottery

\section{Extended Summary}

The subject of the study consisted of glazed pottery discovered from 2017-2018 excavations in Amorium, located in East Phrygia (modern Hisarköy, near Emirdağ, Afyonkarahisar). The finds which were discovered from trenches and drillings and a few from the surface within the Interior Wall (IW) area of the upper city were fragmented and incomplete. The potteries were studied by the method of discrimination of the item groups via total finds rather than similarity of the findspot levels and presentation of each trench and drilling. Thus, the spot areas of finds in table (T.1-16) differ though their grade levels are admissibly close.

Red fabric glazed potteries belonged to food serving items of everyday life and kitchen related storage bowls with and without lids. Most of the fragments belonged to low circular based big sized shallow bowls/dishes, medium sized bowls and big sized plates. Some were probably lidded.

Finds were classified as Monochrome Glazed Pottery, Monochrome Glazed Sgraffito Pottery, Slip-Painted Pottery, and Green and Purple Flecked Ware which was a subgroup of Polychrome Sgraffito Pottery. There were some congregating fragments which belonged to Miletus Type pottery.

Examinations of pottery finds, which were discovered according to trench numbers and levels, provided the interrelated groups at the same level of each trench. In this regard, within the scope of polychrome sgraffito, Green and Purple Flecked finds held a more instructive qualification. The predominant finds group was monochrome transparent green glazed bowls and turquoise was the least. 
Finds of the same sort described as Green and Purple Flecked, Green and Purple Flecked Fette Ware, Purple-Brown Flecked Ware were discovered notably from the Amorium Upper City excavation and from excavation on the Eskişehir Karacahisar Castle located in Middle Asia Minor, from the settlements of Kotyaion, Midaion, Kanlıtaş Tumulus (Kuzfındık Village at the border of Eskişehir/İnönü-Kütahya), and Kilistra (Konya/Gökyurt) -declared without publication, from Western Asia Minor İzmir Kadifekale excavation by unpublished samples, excavations of Ayasuluk Hill in Ephesos, excavations of Artemision, Pergamon, Sardes, Aphrodisias, Hierapolis and Miletos and reached to Ilion/Troas.

Besides monochrome potteries finds of polychrome sgraffito technique were discovered from Balat Ilyas Bey Social Complex examinations contemporaneously and from Ephesos Türbe excavations, and the Manisa Gülgün Hatun Bathhouse as local production. Also, from the same findspot, two finds decorated with monochrome green internally and with monochrome purpur and light green externally were significant in terms of association of both types. Yet, they represented a different ecole in the sense of at least colour scale and the decoration repertoire of Amorium finds. Craftsmanship was more elaborate, and the floral character was more significant as naturalistic. The use of decorations and craftsmanship of polychrome sgraffito finds from Ephesos and the Ayasuluk Hill St. Jean Church Atrium excavation which were described as $14^{\text {th }}-15^{\text {th }}$ century local production were also observed as divergent. A number of polychrome sgraffito fragments were also discovered from İzmir, Kemalpaşa Nif (Olympos) Başpınar Church and Nif Lascarids Palace salvage excavations. They were similar to two potteries from Amorium in terms of edge form and decoration. But the data regarding their production and distribution was insufficient. The tones and use of colours and decoration compositions of finds from İznik (Nicaea) which was a pottery production spot in Post-Byzantine, Early Ottoman period, were different than the Amorium examples.

Elemental fabric analysis of Pergamon finds proved that the monochrome glazed and flecked potteries belonged to the same production group. Similarities were detected between the Green and Purple Flecked wares discovered from Eskişehir, Karacahisar Castle and other pottery groups including the Green Glazed Sgrafitto. Undecorated monochrome green glazed fragments, which were at the same fabric pattern with finds described as Green and Purple Flecked Fette Ware in literature, were examined under the title of 'Fette Ware'. The samples discovered from Pergamon and Sardis were detected by analyses as members of the same production group. It was reported, among Karacahisar Castle finds, that monochrome bowls glazed with green tones and polychrome sgraffito finds indicated a fabric pattern which was defined as fette ware. 
Most of the forms of polychrome sgraffito dishes and big sized plates among Amorium finds were similar to dark and light green monochrome glazed potteries which represented quality. The form, decoration composition, and motifs observed were typical examples of both types in the many other centres mentioned above. Other monochrome glazed Amorium finds which lacked the possibility of being analogue, because of quantitative rarity or lacking typical specifications, may be contemporary to other finds concerning their condition on findspot levels.

More data was needed regarding the rare turquoise-glazed fragments currently discovered from Amorium. For such finds, two different production (Ephesos ve Pergamon) spots; where the exact location was not accurately defined in West Asia Minor, were detected. It was detected by the analyses that they were of Byzantine tradition by the clay character of the slip; but the opaque glaze made with the addition of copper oxide lead-alkaline alloy was an innovation.

Among Amorium examples, a floral decorated bowl which was formed by an underglaze painting technique and brushstroke is reminiscent of Miletus Type potteries by its form and decoration, although the decorative use of the light blue tone was extraordinary when compared to cobalt. As well as the Miletus Type pottery fragments of the Amorium Upper City excavations which were dated to the middle $14^{\text {th }}$ century were published, their decor colours were defined as cobalt blue. Yet, the green glaze of the external surface of some fragments indicated a similarity with the bowl represented here. It was detected that the rare Upper City finds were not of the İznik production Miletus Type. As well as it seems possible that this type of production in Miletus, Akçaabat nearby Ezine, Pergamon, Aphrodisias, Kütahya was known as geographically related to Kütahya; more finds were needed. Forms of slip-painted fragments from Amorium were also alike with monochrome and polychrome glazed sgraffito pots.

When suggestions from other centres were taken into consideration, it seems possible to date the study area to middle $14^{\text {th }}$ century - early $15^{\text {th }}$ century. For counterparts of the Amorium find Miletus Type bowl, middle $14^{\text {th }}-15^{\text {th }}$ century suggestions can be pursued; more data is necessary for a more precise dating. The contribution of other finds of the excavation may suggest a narrower chronology. 


\section{Giriş}

Doğu Frigya'da (bugünkü Afyonkarahisar İli), Ankara'nın güneybatısında yer alan Amorium (Amorion, Hisarköy) antik kentinde 1987'deki yüzey araştırmasının ardından kazı çalışmaları, 1988 yılında, merhum Prof. R. M. Harrison tarafindan başlatılmış, 1993'ten 2009 yılına kadar Dr. Christopher Sherwin Lightfoot tarafindan sürdürülmüss, 2014 yılından bu yana Prof. Dr. Zeliha Demirel Gökalp tarafından yürütülmektedir ${ }^{1}$.

Bu çalışmada değerlendirilen sırlı seramikler de 2017-2018 y1lı buluntuları olup Amorium Yukarı Şehir İç Sur kazı alanında İS-1, İS-2, İS-3, İS-4, İS-5, İS-6, İS-7, İS-9, İS-10, İS-11 ve İS-12 numaralı açmalar ile az sayıda yüzeyden ele geçmiştir² (G. 1). İS-10 ve İS-11 numaralı açmalardan gelen aynı kaba ait olabilecek beyaz hamurlu iki parça dışında ${ }^{3}$, buluntuların tümü kırmızı hamurludur. Günlük yaşamda kullanılan yemek servis kapları, mutfakla ilişkili açık ve kapalı saklama kaplarına ait parçalardır. Bazılarının kapaklı olması muhtemeldir. Buluntular yoğunluk alçak, halka kaideli, büyük boyutlu sığ kâse/çanak, orta boy kâse ve büyük tabaklara aittir.

Açmalardan gelen seramiklerin buluntu seviyelerinin benzer olması nedeniyle, çalışma metodu her bir açmanın ayrı ayrı dökümü yerine, toplam buluntu üzerinden mal gruplarının tanınması yönünde olmuştur. Ancak hazırlanan figürlerin içeriklerindeki buluntuların açma yerleri farklı olsa da kot seviyeleri kabul edilebilir değerde birbirine yakındır (Ek.1- Ek. 2).

Hamur yapıları bakımından farklılık gösteren buluntular, şeffaf yeşil rengin tonları, açık sarı, kavuniçimsi sarı, az miktarda şeffaf renksiz ve turkuaz renk sırlıdır. Bezemesiz veya sgraffito teknikli (çeşitli kalınlıkta) bezeme taşıyan çok az kısmı korunmuş amorf parça sayısı daha çoktur. Profil veren parçaların da çoğu çap veremeyecek kadar küçüktür. Bezemede sıraltı sgraffito, boyama, ek oksit boyalarla renklendirme, astar boyama (slip) ve bir buluntuda hamur tam kurumadan uygulanmış parmak baskı teknikleri kullanılmıştır. Nicelik olarak yeşil sırlı buluntular daha fazladır.

1 Prof. Dr. Zeliha Demirel Gökalp başkanlığında ve T.C. Kültür ve Turizm Bakanlığı izni ve desteğiyle yürütülen Amorium kazıları, Anadolu Üniversitesi Bilimsel Araştırma Projeleri Komisyonunca "Amorium Kazıları Projesi (2015-2018) (Proje no:1501E011) başlıklı proje, Türk Tarih Kurumu tarafindan 2017 yılında “Amorium Kenti Kazıları”, 2018 yılında "2018 Yılı Amorium Kazısı” başlıklı projeler ile desteklenmiştir.

2 Kırık ve noksan durumdaki sırsız günlük kaplara ait buluntular bu çalışma dışında bırakılmıştır. Kentin İ̧ Sur kazıları için bkz. Zeliha Demirel Gökalp vd., "2014 yılı Amorium Kazısı," 37. Kazı Sonuçları Toplantısı, c. 3 (Ankara: T.C. Kültür ve Turizm Bakanlığı Yayınları, 2016), 199-214; Zeliha Demirel Gökalp vd., "2015 yılı Amorium Kazısı,” 38. Kazı Sonuçları Toplantısı, c. 3 (Ankara: T.C. Kültür ve Turizm Bakanlı̆̆ı Yayınları, 2017), 451-460; Zeliha Demirel Gökalp, Ayşe Ceren Erel ve Hasan Y1lmazyaşar, "2016 yılı Amorium Kazısı," 39. Kazı Sonuçları Toplantısı c. 2 (Ankara: T.C. Kültür ve Turizm Bakanlığı Yayınları, 2018), 557-570; Zeliha Demirel Gökalp vd., "Amorium Kazıları 2017," 40. Kazı Sonuçları Toplantısl, c. 3 (Ankara: T.C. Kültür ve Turizm Bakanlığı Yayınları, 2019), 713-725; Zeliha Demirel Gökalp vd., "2018 Yılı Amorium Kazıları", 41. Kazı Sonuçları Toplantısı, c. 4 (Ankara: T.C. Kültür ve Turizm Bakanlığı Yayınları, 2019), 567-577.

3 Bezeme içermeyen bu parçalar niteliği anlaşılamadığından çalışma dışında bırakılmıştır. 


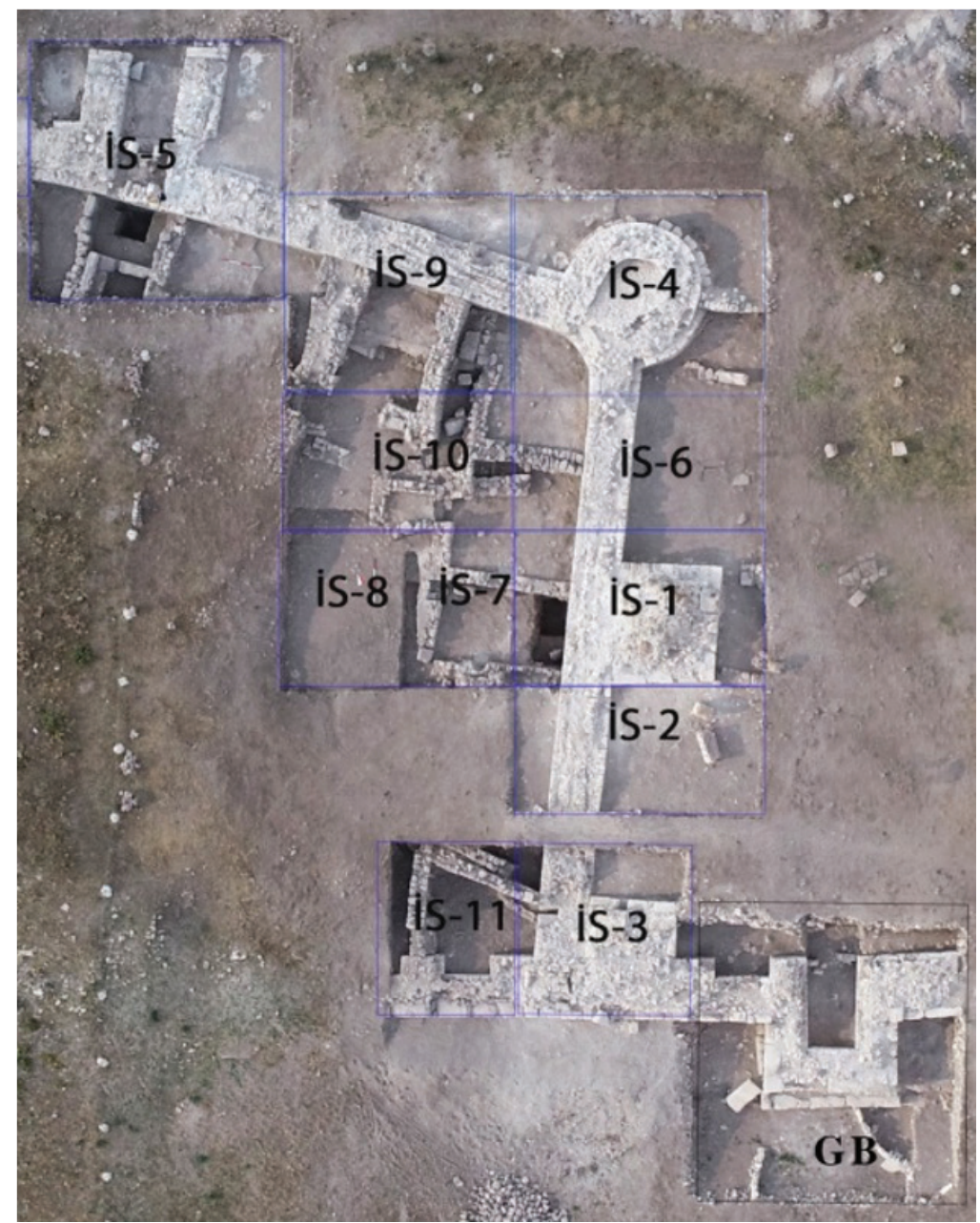

G. 1. Amorium Yukarı Şehir İç Sur kazı alanı, açmalar (Amorium kazı arşivi, 2018)

Çalışmada, bezeme tekniklerine göre sınıflanan seramik gruplarının hamur yapıları bakımından uyumlarını izlemek üzere çıplak gözle tetkikte bulunulmuştur. Başlıca üç grup hamur yapısı belirlenmiştir. Birinci grup, kendi içinde beş alt grup oluşturmuştur. Ele alınan seramik gruplarının hangi tür hamur yapılarında oldukları hamur gruplarını belirten lejantlarla ifade edilmiştir.

\section{Hamur Grupları}

A: Orta sertlikte, ince-sık mikalı ve gözenekli sık beyaz partiküllü, kireç katkılıdır. Genel yapı benzemekle birlikte kapların cidar kalınlıkları, hamurların aşınmışlık durumlarının da etkili olduğu farklı yapılar gözlenmektedir. Sırın ve astarın olmadığı yüzeye dokunulduğunda ele toz tabakası bırakan yapıda dış yüzeye sahiptir. 
A1. Sert, orta miktarda kireç katkıll, şekil ve yoğunluğu yatay ve dikey kesite göre değişkenlik gösteren sık-ince gözeneklidir. Yer yer kireç patlakları mevcuttur.

A2. Orta sertliktedir.

A3. S1k beyaz partiküllü, pütürlü yüzeye sahiptir. S1k mika içeriği ile A1'e yakındır.

A4. A3'e göre daha az yoğunlukta iri plakalar hâlinde yaldız mikalı iri ve sık gözenekli, yer yer iri taşçıklı ve kumlu içeriği ile kaba yapılıdır.

A5. Sık, beyaz-siyah partiküllü, yer yer iri gözenekli yapısı ile sır ve astar özellikleriyle benzer, fakat yer yer iri gümüş renkte mika ile farklıdır.

B: A’ya benzeyen hamur daha sert, daha az gözenekli sıkı, az-ince mikalıdır ancak beyaz partikül gözlenmez.

C: A’ya ve B’ye göre daha kaba hamurludur. Sert, az, ince mikalı daha pütürlü yüzey, yer yer iri kuvars taneleri ile gözenek yoğunluğu A'yla benzer. Dişta yer yer iri taş ve kireç patlakları vardır. Beyaz, sarı renkte yer yer iri, yoğun mikalı, özellikle iri kireç taneli, gözeneklidir. Bu grup içinde birkaçı daha iyi ve az katkılı olmaları bakımından kalitelidir. Çoğunlukla gözenekli, siyah-beyaz partikül daha belirgin, daha yumuşak hamurlu varyasyon vardır.

\section{Tek Renk Sırlı ve Tek Renk Sgraffito Seramikler}

Yeşil sırlı buluntular, başlıca parlak koyu yeşil, parlak açık yeşil, sarımsı yeşil renk olarak belirirler. Renk skalaları kendi içlerinde astar yapıları ile dış yüzey işlemleri, cidar kalınlıkları bakımından da uyum gösterirler.

\section{Parlak Koyu Renk Yeşil Sırlı Kaplar (T. 1-4)}

İS-3, İS-4, İS-5, İS-7, İS-9, İS-11, İS-12 açmalarından ele geçmişlerdir. A tipi hamur yapısı gösterirler. 5 YR 5/6 sarımsı kırmızı ve 5 YR 6/6 kırmızımsı renk skalasına otururlar. Sırlama öncesi iç yüzey beyaz astarla kaplanmıştır. T.1: 1'deki ağız parçasında düzensiz uygulanmış olsa da, mat sık dokulu astar dış yüzeyde ağız kenarından gövdeye doğru geniş bir kuşak olarak uygulanmıştır. Bu görüntü diğer yeşil sırlılara göre fark yaratır. Korunan kısımlardan hareketle bazılarında gövdenin yaklaşık ortasina kadar uzanır (T.1: 4, 5).

Sır dış yüzeyde çoğunlukla dudak altında veya ağız kenarında ince bir şerit olarak (T.1: 1, 2; T.3: 8; T.3: 1, 2, 3) uygulanmıştır. Biraz daha geniş (T.1: 7; T.3: 5, 6, 7) veya astarı tam kaplamayacak kadar oldukça geniş (T.2: 1-4; T.3: 4, 6) uygulamalar da vardır. Bazı parçaların küçük olması, sağlıklı gözleme izin vermez. Sırlar ince çatlaklara sahiptir; kireç patlakları vardır; renk nüanslıdır; yer yer pigmentler belirgindir; siyah, siyah-kahverengimsi kümelenmeler oluşmuştur (T. 3: 5). Diş uygulamada yer yer düzensiz akmalar yapmıştır (T.1: 1, 5; T.2: 6; T.3: 5, 8). Pigment dalgalanmalarının hatalı üretim aşamasına dönüştüğü, rengin tutturulamadığı (T.2: 5) sırın hatalı piştiği görülen parçalar da mevcuttur (T.1: 3; T.2: 2). 
Bazı ağız kenarı parçalarının iç ve/veya dış yüzeylerinin ağız kenarı ya da dudak üzerleri siyah-siyahımsı (T.1: 1, 2, 7; T.3: 5, 8), kahvemsi yeşil renk (T.1: 5) görünümdedir. Dar veya geniş ağız tablalı kenar parçalarının bazılarında bezemelerin az bir kısmı korunmuştur. Bezemede içleri siyah (T.2: 2, 4), siyah-zeytin yeşilimsi renk (T.2: 1) görünümde kazıma çemberler, çemberler arasında aralıklı yerleştirilmiş dikey paralel ya da eğik kazımalar izlenmektedir ${ }^{4}$ (T.3: 2, 3, 4, 6).

Bu gruba ait parçalar, büyük tabak, kâse veya çanaklara aittir ${ }^{5}$. Bir kısmı ağız çap1 22.0-24.0 cm aralığında basit ağı kenarlı, yarı-küresel ${ }^{6}$ (T.1: 1, 2), küresel gövdelidir ${ }^{7}$ (T.1: 4-7). Bir ağız kenarı içten kalınlaştırılmıştır.

Diğer bir form çeşidi, 27.0 cm'ye varan ağı çapları ile daha geniş ve yayvan gövdeli çanaklardır. Dışa açılan dar ağız tablası, düzleme paralel (T.2: 1, 2) veya hafif açılıdır ${ }^{8}$ (T.2: 3, 4). İki açık kap, dışa doğru açılı uzanan daha geniş ağız tablalı çan (T.2: 5) veya küresel gövdelidir. T.2: 6'da kenara geçiş dış yüzeyden de vurguludur.

Ağız tablasının içte kenar duvarından bir çıkıntı ile kademeli olarak yükseldiği sivri $^{9}$ (T.3: $\left.1,4,6\right)$ veya yuvarlak dudaklı (T.3: $\left.2,3,5\right)$ büyük tabak ve çanaklarda tablaların yükselme açıları çeşitlilik göstermektedir ${ }^{10}$. İçte beliren çıkıntılar olasılıkla kapakların oturması içindir. T.1: 3'te yer alan içten kalınlaştırılmış ağız kenarı parçası bu tip kaplar için kapak fonksiyonu sağlamış veya kâse olarak biçimlenmiş olabilir ${ }^{11}$. T.3: 6'da yer alan parça olasılıkla düzleme yatay, iç bükey geniş ağız tablalı, sivri dudaklı çanağa aittir. T.3: 7, 8'deki parçalar da olasılıkla halka kaidenin üzerinde

4 Karacahisar Kalesi'nden form ve benzer anlayışla yapılmış az farklı benzer örnekler için bkz. Muradiye Bursalı, "Eskişehir Karacahisar Kalesi Sgraffito Dekorlu Ortaçağ Seramikleri” (Yüksek Lisans Tezi, Anadolu Üniversitesi, 2007), Lev. 84, 85, 86, Lev. 88 (2), Lev. 91.

5 Ağız kenarı ve gövde parçalarının çok küçük olması, yükseklik alınmasını; kaidelerin eksikliği ise kesin bir form çıkarılmasını güçleştirmektedir.

6 Amorium Yukarı Şehir kazısı Bizans sonrası tabakalarından (UU-TT) benzerleri için bkz. Beate BöhlendorfArslan, Die Glasierte Byzantinische Keramik aus der Turkei (İstanbul: Ege Yayınlar1, 2004), Teil. III, Taf. 105 (416, 418- R.55 olarak kodlanmış ağız kenarlı çanaklar); Aphrodisias buluntusu için bkz. Veronique François, "Element Pour I'historie Ottomane d'Aphrodisias: la Vaiselle de Terre," Anatolia Antigua 9 (2001), 166, Pl. $10(89,93)$.

7 Miletos buluntusu için bkz. Böhlendorf-Arslan, Die Glasierte Byzantinische Keramik aus der Turkei, Teil. III, Taf. 145 (730).

8 Aphrodisias buluntusu için bkz. François, "Element Pour I'historie Ottomane d'Aphrodisias: la Vaiselle de Terre," 167, P1. 11 (107).

9 T.1: 1 ve T.5: 1'de olduğu gibi dudağın dikey sivri çıkıntı hâlinde bulunması, içteki diğer sivri çıkıntı ile birlikte iki yandan sınırlanmış derin bir yüzeyi oluşturur. Bu alan bazen düz, bazen iç bükeydir. Bu tip tablalar pervazlı kenar olarak da isimlendirilir.

10 Amorium Yukarı Şehir kazısı Bizans sonrası tabakalarından (UU) benzeri için bkz. Böhlendorf-Arslan, Die Glasierte Byzantinische Keramik aus der Turkei, Teil. III, Taf. 107 (432); Miletos buluntusu için bkz. Böhlendorf-Arslan, Die Glasierte Byzantinische Keramik aus der Turkei, Teil. III, Taf. 145 (736); Aphrodisias buluntusu için bkz. François, "Element Pour I'historie Ottomane d'Aphrodisias: la Vaiselle de Terre," 167, Pl. 11 (110-112); Varyasyon olarak Beylikler Dönemine tarihlenmiş Tire Kutu Han buluntusu için bkz. Hasan Uçar ve Aygül Uçar, “Tire Kutu Han Kazısı Beylikler ve Osmanlı Dönemi Seramikleri,” Sanat Tarihi Dergisi 27/1 (2018), 10, Tab.3a.

11 Örnek için bkz. Erica D'amico, "Byzantine Finewares in Italy (10th to 14th Centuries AD): Social and Economic Contexts in the Merditerranean World," (Doktora Tezi, Durham University, 2011), 333, fig. 5.8. 
düzleşerek keskin bir karine ile 45 derecelik açıyla yükselen, ağız kenarlarının da gövdeden sert bir dönüşle kısa ve düşey olarak şekillendiği çanaklardır ${ }^{12}$.

Hamur, astar ve sir görünümleri ile bu kaplara ait olabilecek halka kaidelerin çapları 7.0-10.0 cm arasındadır. ${ }^{13}$ İS-11, İS-12 numaralı sondajlardan yaklaşık aynı seviyeden gelen düzleme iç uçtan basan, dıştan açılı yükselen görünüm veren kaideler bir grup gibi durmaktadır (T.4: 3-6).

\section{Tablo 1}

Tek Renk Sirlı Bezemesiz ve Sgraffito Seramikler (L. Doğer- M. E. Armağan, 2020)

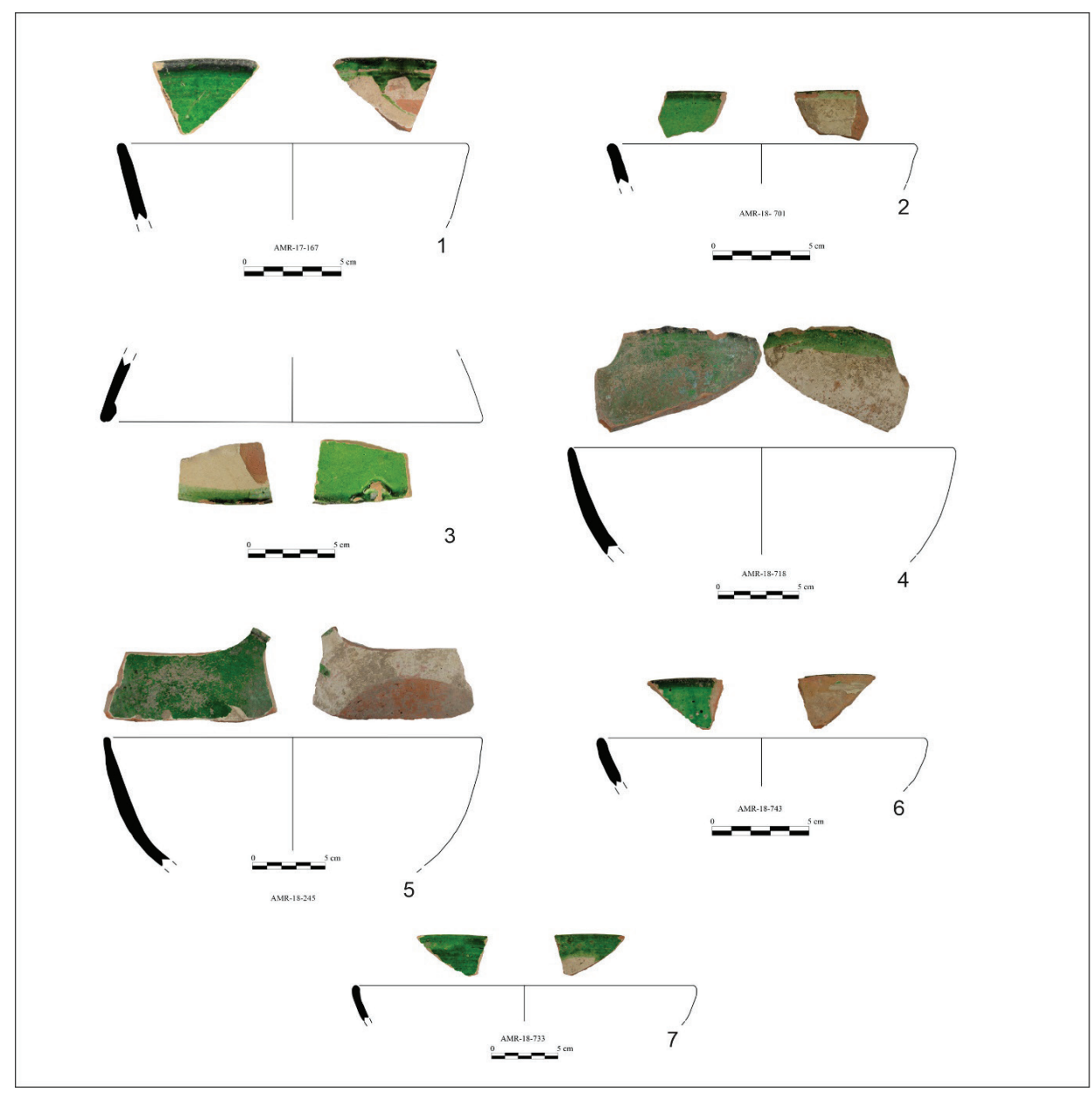

12 Karacahisar Kalesi Yeșil ve Erguvan Lekeli çanaklar içinde ünik olarak tanımlanan tam form için bkz. Muradiye Öztaşkın, "Eskişehir Karacahisar Kalesi Ortaçağ Seramiklerinden Bir Grup: Yeşil ve Erguvan Lekeli Seramikleri,” 8. Ortaçă̆ ve Türk Dönemi Kazıları ve Sanat Tarihi Araştırmaları Sempozyumu Bildirileri (İstanbul: Pamukkale Üniversitesi Fen-Edebiyat Fakültesi Sanat Tarihi Bölümü Yayınları, 2010), 534, Lev.3.a; Aphrodisias buluntusu için bkz. François, "Element Pour I'historie Ottomane d'Aphrodisias: la Vaiselle de Terre," 167, Pl.11 (105-tek renkli); 176, Pl. 17 (174-çok renkli).

13 Amorium Yukarı Şehir kazısı Bizans sonrası tabakalarından (UU) benzeri için bkz. Böhlendorf-Arslan, Die Glasierte Byzantinische Keramik aus der Turkei, Teil. III, Taf. 106, 425, 426. 


\section{Tablo 2}

Tek Renk Sırlı Bezemesiz ve Sgraffito Seramikler (L. Doğer- M. E. Armağan, 2020)

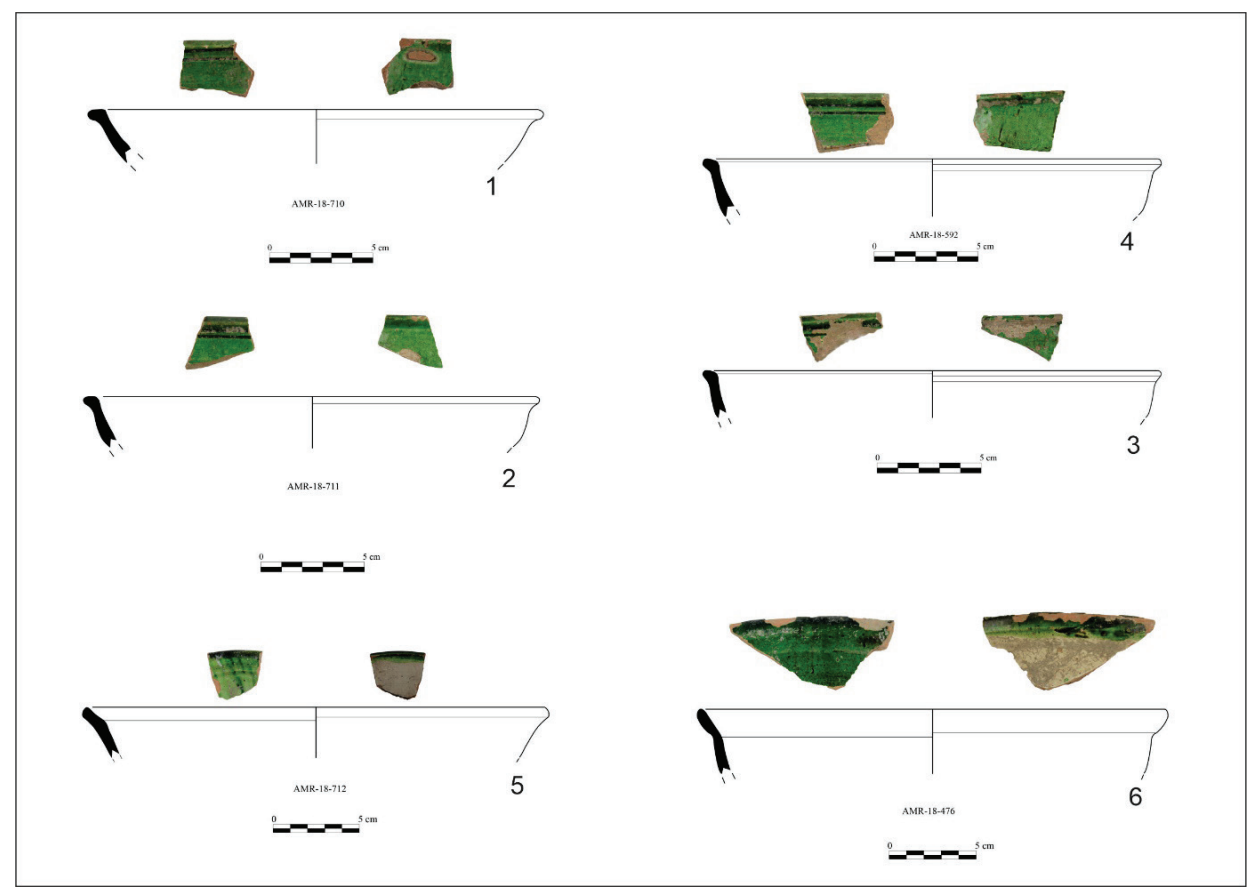


Tablo 3

Parlak Koyu Renk Yeşil Sırlı Kaplar (L. Doğer- M. E. Armağan, 2020)

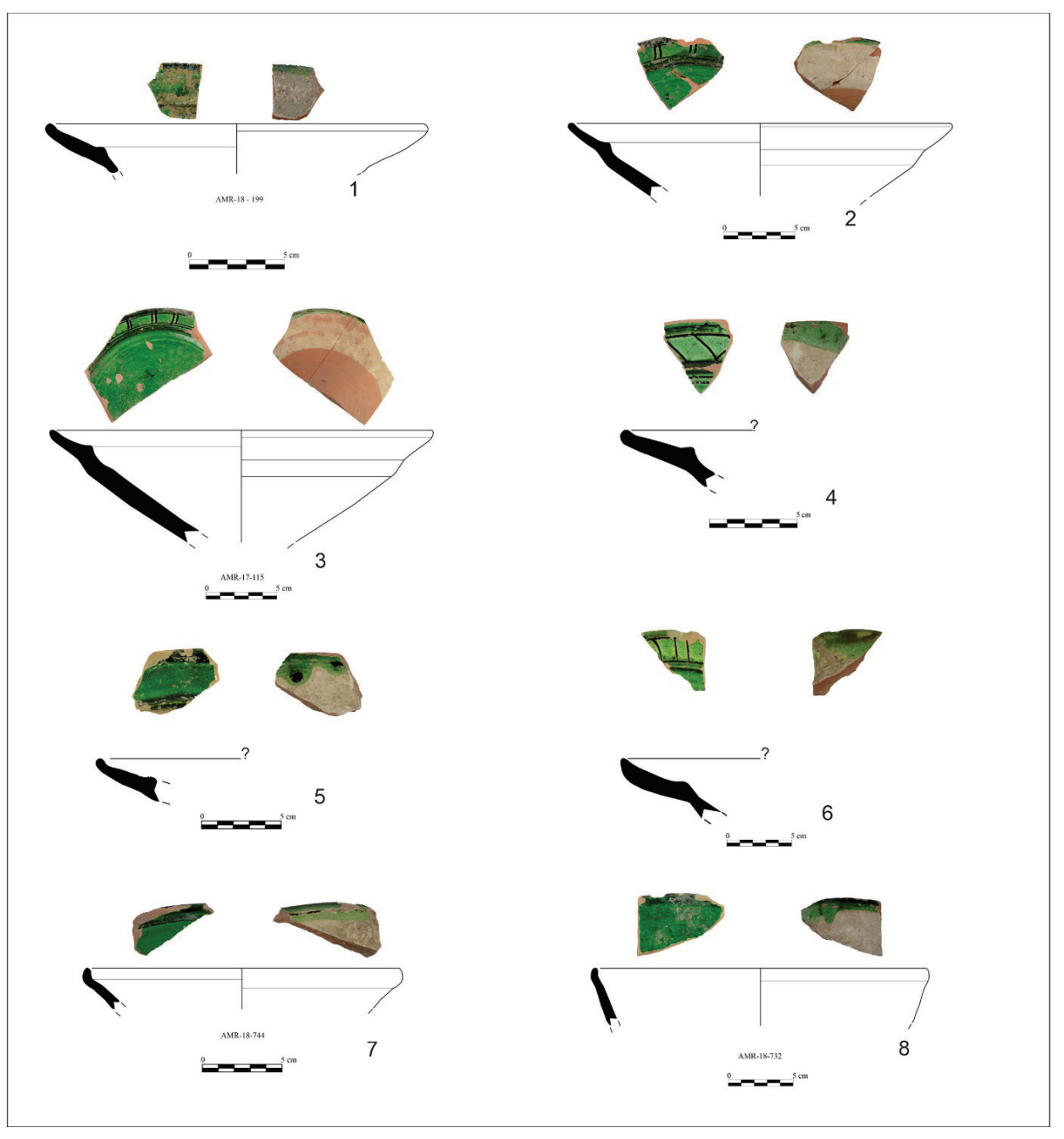




\section{Tablo 4}

Parlak Koyu Renk Yeşil Sırlı Kaplar (L. Doğer- M. E. Armağan, 2020)
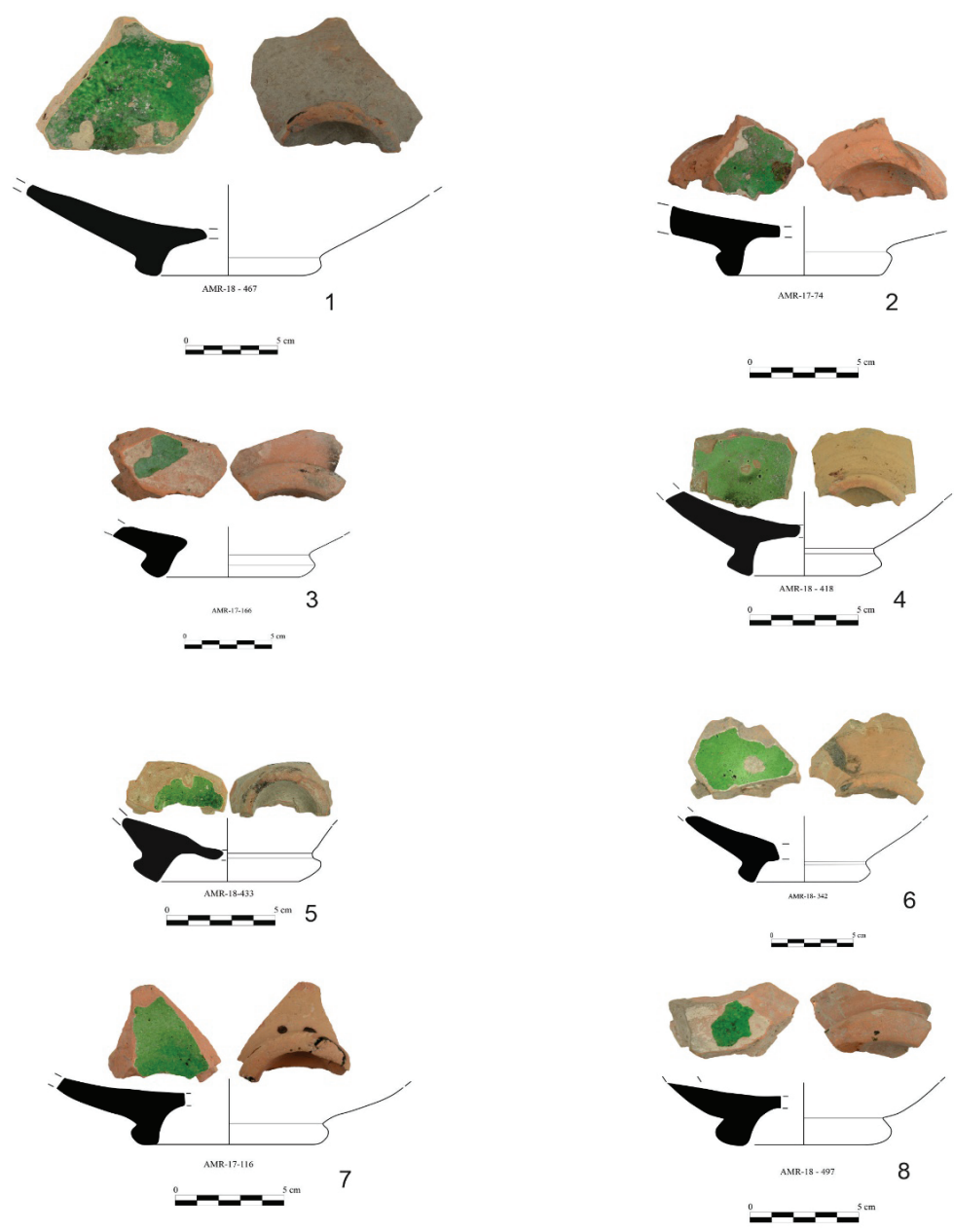

\section{Parlak Açık Renk Yeşil Sırlı Kaplar (T. 5)}

İS-1 açmasından iki ağız kenarı ve gövde parçası ile bir kısa halka kaidenin sır rengi, önceki gruba göre daha bakır yeşili görünümdedir. Hamur rengi daha sarımsı kırmızıdır. A tipi hamur yapısı gösterirler. Beyaz astar iç yüzey ile dış yüzeyde gövdenin yaklaşık 1/3'üne uygulanmıştır. Sır ince çatlaklara sahiptir, nüanslıdır, sık sık koyu yeşil pigmentler belirgindir, (T.5: 3), iri kireç patlakları vardır. Dış yüzeyde dudak altını çevreler, yer yer düzensiz akmıştır (T.5: 2). T. 5: 1'de üçayak izi vardır.

Büyük tabak grubuna ait parçalarda, içte gövdenin ağızdan önce keskin bir çıkıntı yapan küçük omurgası vardır. Dudak yukarı çekik sivri (T.5: 1) ya da yuvarlak sonlanır. Ağız çapları $29.0 \mathrm{~cm}$ civarındadır. Parçaların cidar kalınlıkları birbirleriyle uyumludur. 
Tablo 5

Parlak Açık Renk Yeşil Sırlı Kaplar (L. Doğer- M. E. Armağan, 2020)

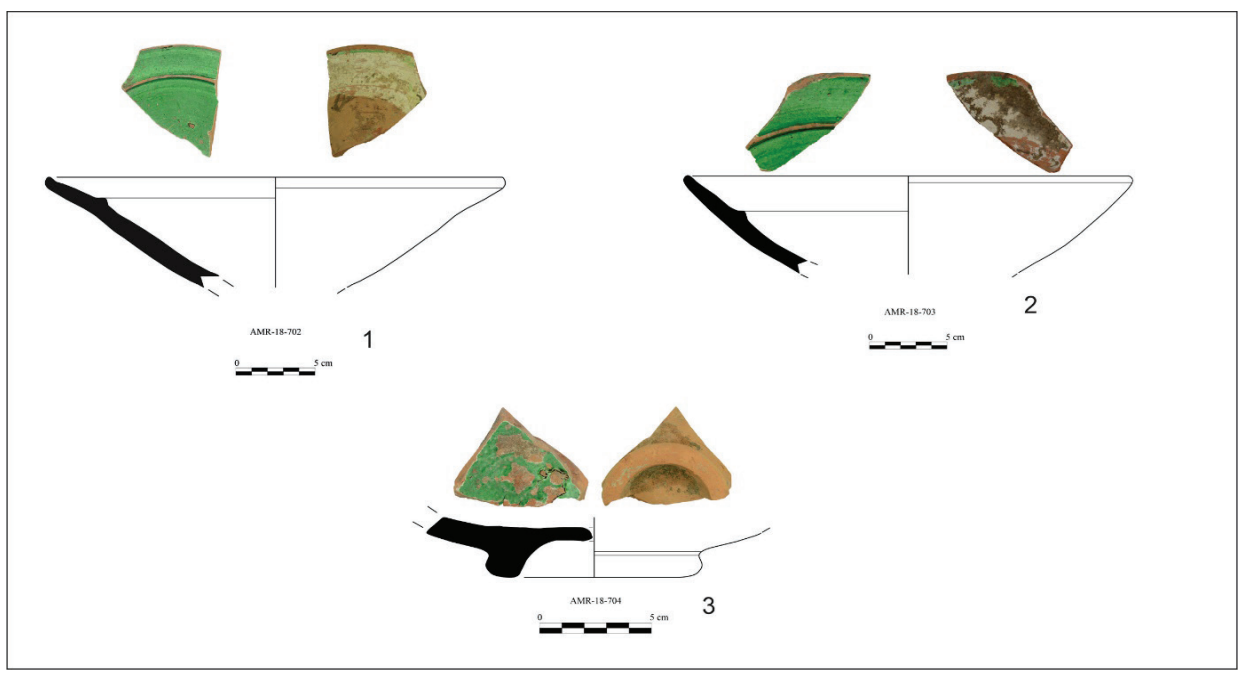

Sarımsı Yeşil Renk Sırlı Kaplar (T. 6)

İS-1, İS-3, İS-4, İS-5, İS-7, İS-10, İS-11 açmalarında ele geçmişlerdir. Sır renkleri sarımsı yeşil ton gösterir. Öncekilere göre daha ince uygulanmıştır, içindeki renk dalgalanmaları daha fazladır, açık, koyu yeşil, kahverengimsi pigmentler farklı boyutta ve sıktır. Bu buluntularda sarımsı krem, pembemsi krem astar izlenmiştir. Altta kullanılan astar rengi sır görünümünü değiş̧irdiğinden, arka yüzeyde düzensiz sürülen astarlı kısımlar ile hamurun rengi, sırda açıklı koyulu görünümlere neden olmuştur (T.6: 3). Çap 19.0 cm'lik düz dip parçasının da iç yüzü sarımsı renk sırlı iken dış yüzünde beyaz astar üzerine koyu ancak parlak yeşil bir sir mevcuttur (T.6: 6).

Parçalar daha az özenli mutfak kaplarına aittir, hamur yapısı da daha kabadır. Olasılıkla dışa doğru açılarak oluşmuş $24.0 \mathrm{~cm}$ çapındaki yüksek ağız kenarlı derin kabın dış yüzey ağız kenarında, yatay sığ yiv dizileri vardır. Bunlar kabın üzerini kapatacak bir örtücünün bağlanması sırasında kaymaması amaçlı olabilir (T.6: 1). T.6: 4'deki $14.0 \mathrm{~cm}$ çapındaki kabın (boyun kısmı?) dış yüzey ağız kenarındaki derin yiv, bağlantıyı sağlayan bir ip veya telin kaymaması işlevli olmalıdır. Ağız kenarının dıştan kalınlaştırılması da bu işlevi destekler. Ağız çapı $15.0 \mathrm{~cm}$ olan konik gövdeli, orta boy kâse diğer bir form çeşidini temsil eder (T.6: 2). Ağız çap1 $18.0 \mathrm{~cm}$ olan daha sığ gövdeli orta boy kâsenin ağız kenarının iç yüzündeki kademe, kapak oturduğunu göstermektedir (T.6: 3). Dıı̧ yüzeyinde çark izleri belirgin, zeytin yeşili renk sırlı, düzleme paralel dışa çekik kenarlı parça, olasılıkla kapaklı sı̆̆ bir kaba aittir (T.6: 5). İç yüzeyi sarımsı yeşil, dış yüzeyi parlak koyu yeşil renk, sırlı düz dip (T.6: 6) ile astarsız ince yeşilimsi sır sürülmüş bir kulp parçası da olasılıkla sürahi benzeri veya saklama kaplarına aittir (T.6: 7). 


\section{Tablo 6}

Sarımsı Yeşil Renk Sırlı Kaplar (L. Doğer- M. E. Armağan, 2020)

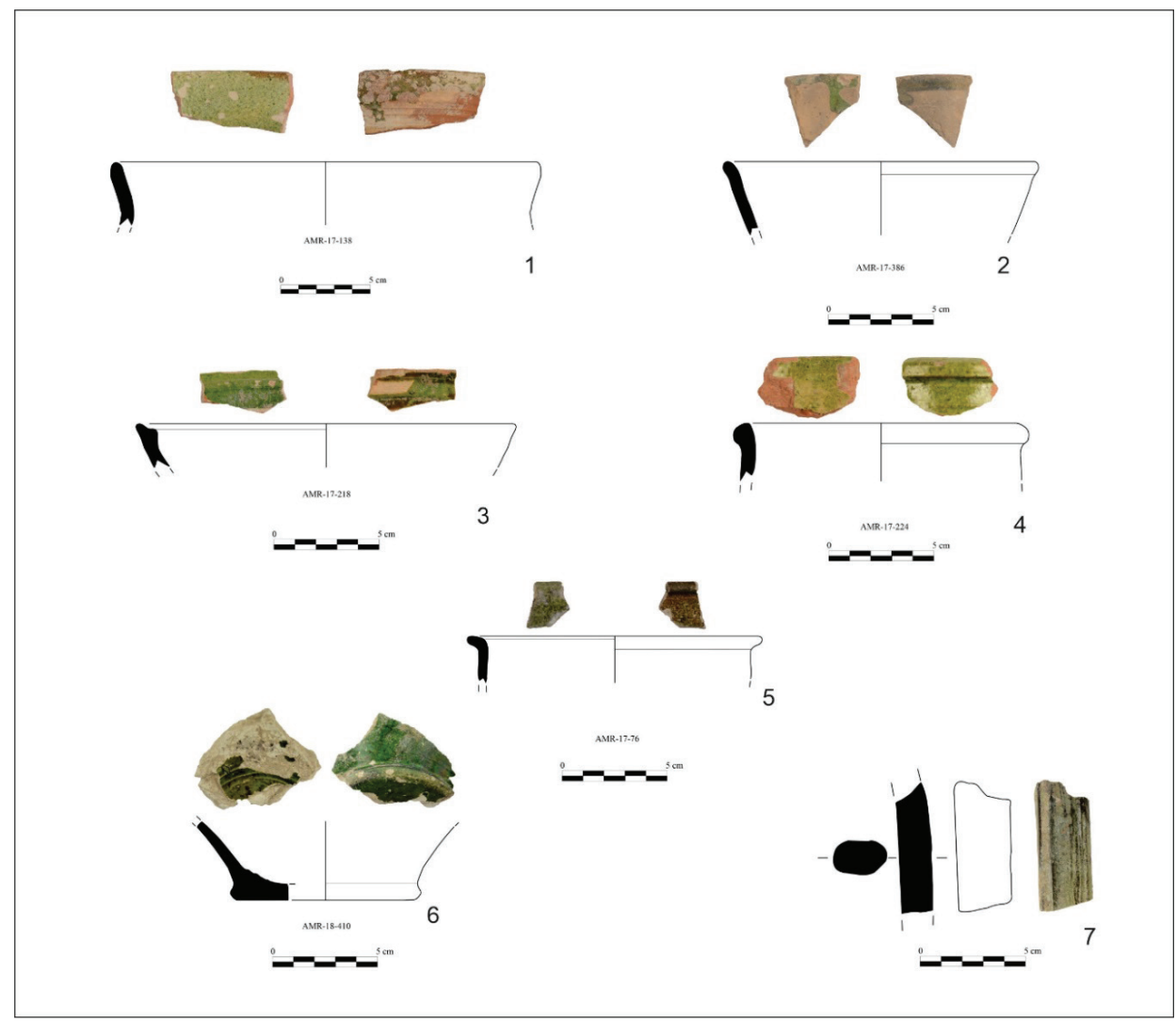

\section{Açık Sarı Renk Sırlı Kaplar (T. 7)}

Bu grup İS-1, İS-6 ve İS-11 açmalarında ele geçmişlerdir. Beyaz astarlı, açık sarının tonunu taşıyan değerlerde sırlıdırlar. Sır küçük çatlaklara sahiptir. Sarımsı kırmızı renkte A tipi hamur yapısı gösterirler. Çapları $23.0 \mathrm{~cm}$ civarında basit ağızlı, orta boy kâselerdir. T.7: 1'deki ağız kenarı parçasının iç yüzeyinde, sgraffito ince band içinde kıvrım dalları temsilen spiral bezeme bulunur. Kazımalar açık kahverengimsi görünümdedir. Dış yüzey, beyaz astarlı ve dudak üzeri dâhil açık yeşil sırlıdır. Yeşil rengin skalası, A2 grubunu anımsatmaktadır. T.7: 3'deki ağız kenarı ve gövde parçasının da her iki yüzü astarlı ve sırlıdır. İki yüzde de ağız kenarını gövdeden daha koyu sarı renkte sır çevreler. T.7: 2'deki parçada astar ve sır çok aşınmıştır. 
Tablo 7

Açık Sarı Renk Sırlı Kaplar (L. Doğer- M. E. Armağan, 2020)

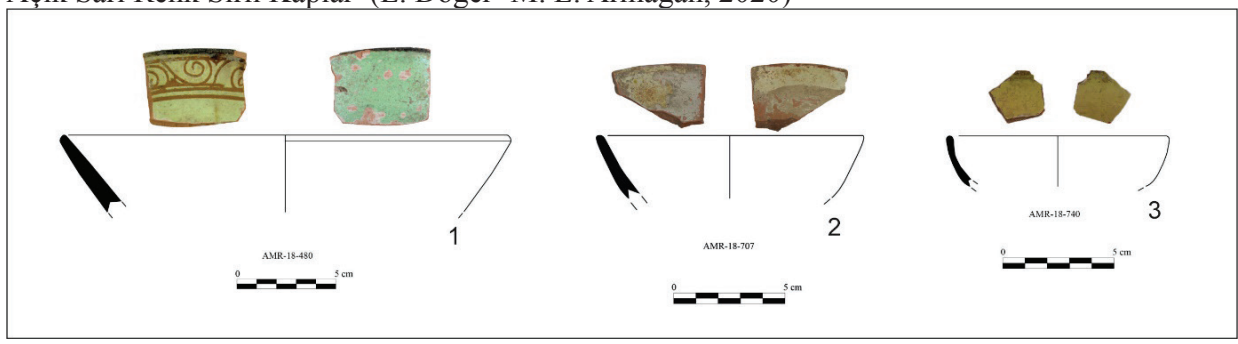

\section{Kavuniçimsi Sarı Renk Sırlı Kaplar (T. 8)}

İS-5 ve İS-11'de ele geçmişlerdir. C tipi hamur yapısı gösterirler. İri kireç patlakları bulunan kaba hamurlu mutfakla ilişkili açık $($ T.8: 2,5$)$ ve kapalı kap boyun, kulp (T.8: 4, 5) parçalarıdır. Beyaz (T.8: 3), pembemsi krem (T.8: 4) astarlar gözlenir. Sırlar çatlaklı ve homojen görünümde değildir. Uygulanma biçimleri de özenli değildir. Kavuniçimsi sarı (T.8: 2, 4, 5) hardalımsı koyu sarı renk izlenmektedir. Dikey çift kulplu saklama veya pişirme kabı içte açık yeşil, dışta açık kahverengi kavuniçimsi sarı renk sirlıdır (T.8: 3).

\section{Tablo 8}

Kavuniçimsi Sarı Renk Sırlı Kaplar (L. Doğer- M. E. Armağan, 2020)

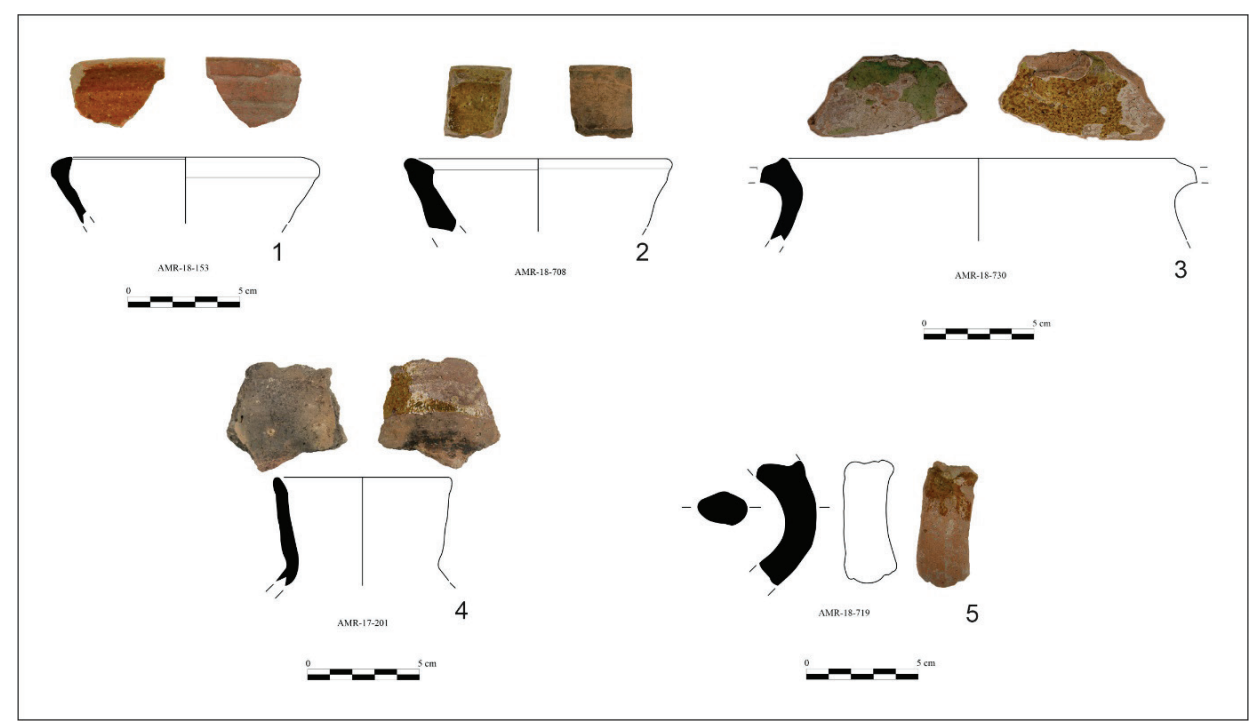

\section{Turkuaz Renk Sirlı Kaplar (T. 9)}

İç yüzeyi turkuaz renk sırlı az sayıda buluntu vardır. İS-7'den +976.88 m. kodundan ele geçmiş bir ağız kenarının dış yüzeyi, ağız kenarı altından itibaren şeffaf açık sarımsı renk sırlıdır (T.9: 1). Hamur 2,5 YR 5/8 kırmız1, B tipindedir. 
Tablo 9

Turkuaz Renk Sırlı Kâse ve Sıraltı Boya Teknikli Milet Tipi Kâse (L. Doğer-M. E. Armağan, 2020)

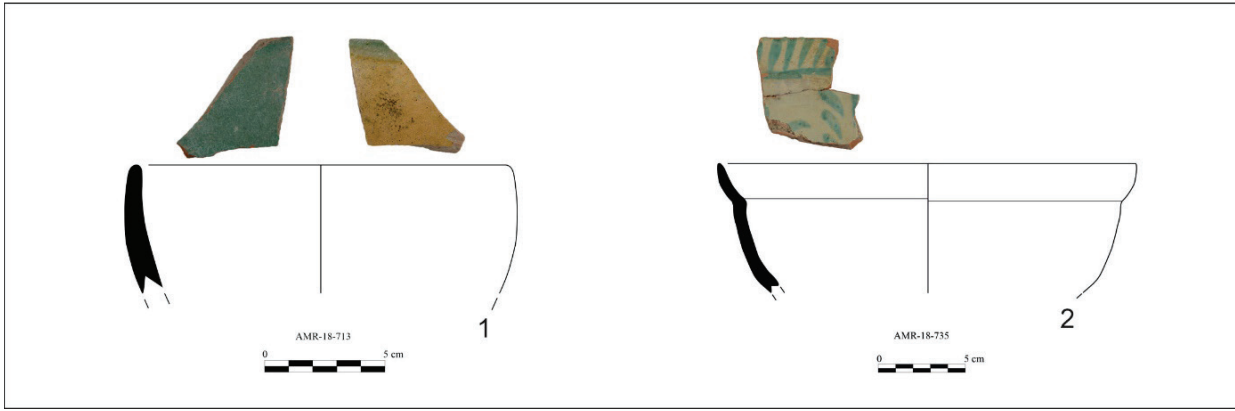

Çok Renkli Sgraffito Seramikler (T. 10-14)

Yeşil ve Erguvan Lekeli Kaplar

Çok renkli sgraffito seramiklerin alt grubudurlar. Bu grup buluntular sgraffito (ince ve/veya kalın kazıma) tekniği de kullanılmasına rağmen bezemesinde öne çıkan oksit renklendirmelere istinaden isimlendirilmişlerdir. Bezemede yer alan yeşil ve erguvan renk oksit boyanın (sır esaslı kahverengimsi mangan, kahverengimsi tonlar da) renk uyumu görsel bir estetik algıyı ön plana çıkarır. Hamur özelliğinden dolayı Yeşil ve Mor Lekeli Yağlı Mal ${ }^{14}$ ya da "Eflatun/erguvan-Kahverengi Lekeli (purple-brown dots $)^{15}$ olarak da adlandırılmışlardır. Sarı rengin de az veya çok bezemeye katıldığı buluntular da izlenmektedir ${ }^{16}$.

T.10-14'de yer alan Amorium buluntuları, İS-6, İS-7, İS-9, İS-10, İS-11, İS-12 açmalarında ele geçmişlerdir. A tipi, mikalı, kireç katkı1ı, gözenekli kırmızımsı sarı tonlarında hamur yapısı gösterirler. Sık dokulu beyaz astar, iç yüzey ile dışın yarıya kadarını kaplar. Açık yeşil kurşunlu sır parlaktır ancak kılcal çatlaklar, irizasyon ve kireç patlakları mevcuttur. Sır astarın tamamını örtmez ve dış yüzeyde biraz daha koyu tonlarda olabilmektedir ${ }^{17}$.

14 Hamurun dokunulduğunda, elde kırmızı bir toz tabakası bırakan yapısı "Yağlı Mal (Fette Ware)" olarak karakterize edilir. Böhlendorf-Arslan, Die Glasierte Byzantinische Keramik aus der Turkei, 148, Teil I; Pergamon örneklerinin hamuru için sabunsu doku (soapy touch) tanımlaması yapılır ve ayırıcı özellik olarak ortaya konur. Bkz. Sylvie Yona Waksman ve Jean Michel Spieser, "Byzantine Ceramics Excavated in Pergamon: Archaeological Classification and Characterization of the Local and Imported Productions by PIXE and INAA Elemental Analysis, Mineralogy and Petrography," Materials Analysis of Byzantine Pottery (Washington: Dumbarton Oaks Research Library and Collection, 1997), 123, Grup 6 II, series F.

15 Hamur özelliğinden dolayı sabunumsu hissi bırakan (soapy fell) olarak da tanımlanır. Joanita Vroom, "Medieval Pottery from the Artemision in Ephesos: Imports and Locally Produced Wares," Spatantike und Mittelalterliche Keramik aus Ephesus (Wien: Österrichische Akademia der Wissenschaften, 2005), 26.

16 Bazı buluntularda kazıma ile uygulanan motif etrafında kazımaları takiben, sırlama sonrası oluşmuş çok az miktarda sarı görüntü belirir. Araştırmacılar bunu kahverenginin kullanıldığı oksit boyaların firın ısısında verdiği reaksiyon olarak açıklar. Bu durum çok kalın kazımaların kullanıldığı Ege Tipi Orta Bizans Kaplarında da konturlar çevresinde izlenir. Pek çok örnekte yeşil ve eflatunun yanı sıra sarı lekeler hâlinde bilinçli olarak kullanılmıştır.

17 Sır, dış yüzeyde astar hizasının yarısına kadar gelerek sonlanır. Bu uygulama, Yeşil ve Erguvan Lekeli mal grubunda çok izlenmektedir. 
Tablo 10

Yeşil ve Erguvan Lekeli Kaplar (L. Doğer- M. E. Armağan, 2020)

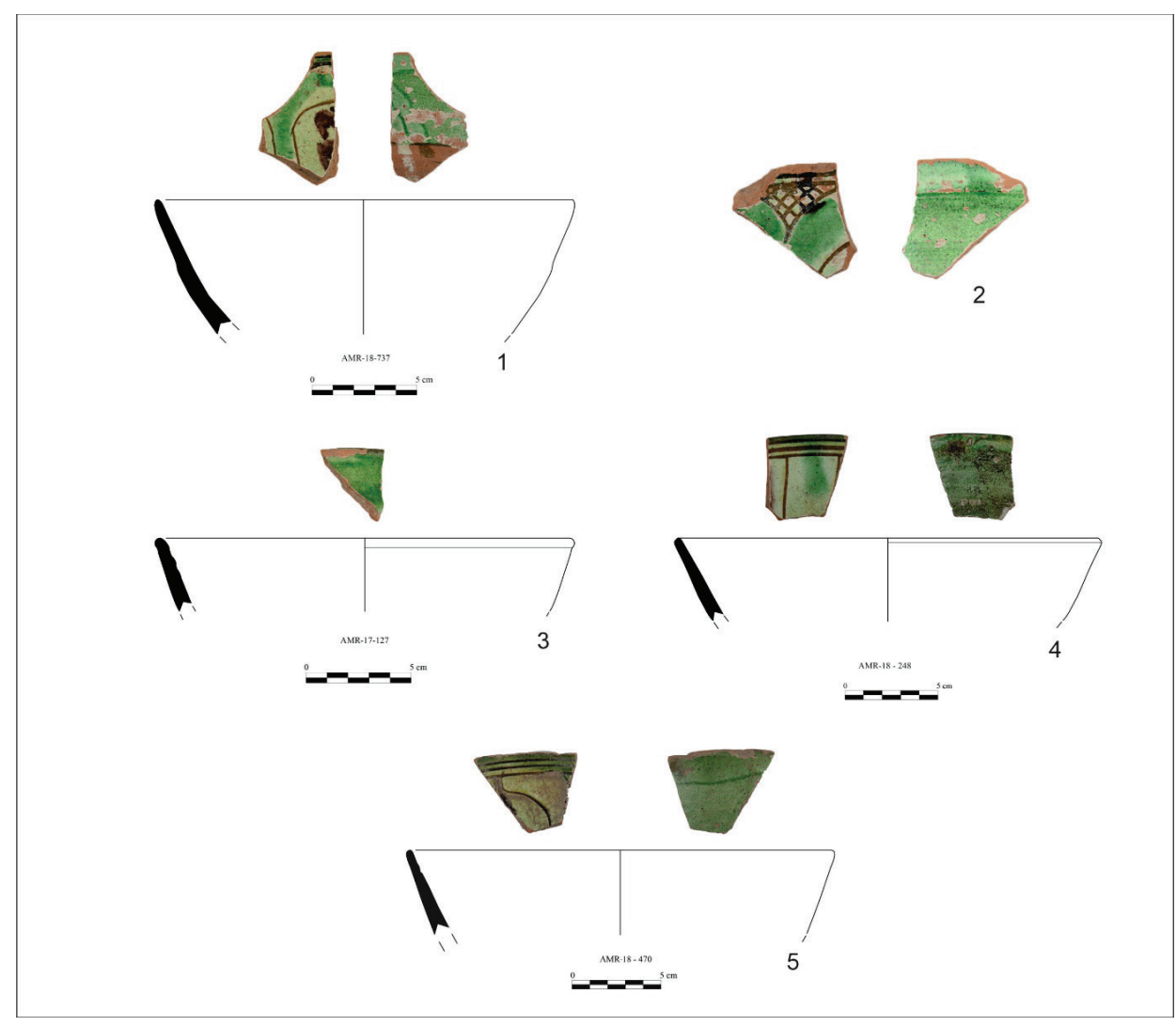

Buluntuların hepsinde bezemede sgraffito (farklı kalınlıkta) tekniği ile oksit boya ya da $\operatorname{sir}^{18}$ kullanılmasına rağmen kazımanın karakteri, erguvan ya da mangan rengin tonları, yeşil rengin nüansları, sarı rengin kullanım biçimi farklılık gösterir. Genel algida gruplar belirir.

B1. 1- (T. 10: 1-3) Buluntular, 23.0-24.0 cm ağız çapına sahip, kaideden dişa doğru incelerek şekillenen basit ağız kenarlı çanaklardır' ${ }^{19}$. T. 10: 1, 2, 3; T. 10: 5; T. 12: 4 'te bezemelerin çok az bir kısmı korunmuş olmasına rağmen Yeşil ve Erguvan Lekeli seramiklerde en sık kullanılan kompozisyonlara sahip oldukları belirlenebilmektedir (G. 2).

18 Karacahisar seramiklerinde kabın iç yüzeyindeki renklerin oksit boya ile değil, sır ile uygulandığı düşünülmektedir. Kazıdan ele geçen bazı kaplar üzerinde süsleme tekniğine adını veren erguvan rengin açık yeşil ile açık kahverengi sırın birleşmesiyle elde edildiği gözlenmiştir. Karacahisar'da bezemesiz, sırlı bir kap üzerinde bu uygulamanın açıkça görüldüğü belirtilmektedir. Bkz. Öztaşkın, "Eskişehir Karacahisar Kalesi Ortaçağ Seramiklerinden Bir Grup: Yeşil ve Erguvan Lekeli Seramikleri," 527.

19 Bazı benzer formlar için bkz. Vroom, "Medieval Pottery from the Artemision in Ephesos: Imports and locally produced wares,” 40, P1. II, 19; Bursal1, "Eskişehir Karacahisar Kalesi Sgraffito Dekorlu Ortaçağ Seramikleri," Lev. 92. 


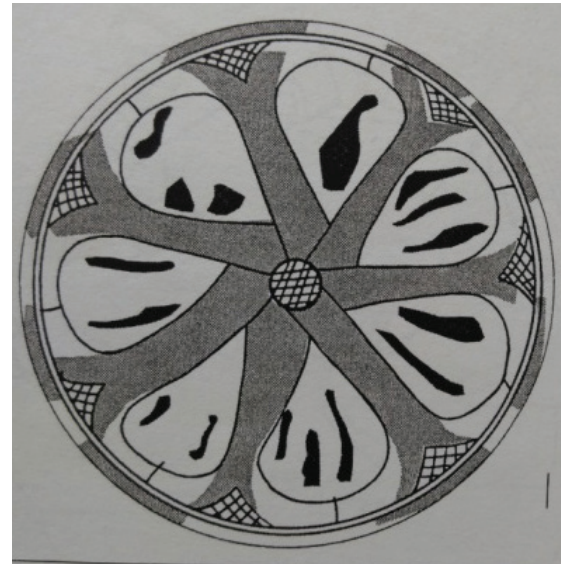

G. 2. Yeşil ve Erguvan Lekeli Kâse (Amorium Yukarı Şehir, Alan UU, Bizans Sonrası Tabaka; Böhlendorf-Arslan, Die Glasierte Byzantinische Keramik aus der Turkei, Teil. III, Taf. 108: 435)

T.10:1'de kabın merkezinden çıkan kazıma radyal çizgilerin ağız kenarına doğru birleşmesiyle elde edilen iri yapraklı çiçek motifi sgraffito olarak işlenmiş olmalıdır. Yaprak içleri kahverengimsi mangan oksit boya ile düşey eksende stilize bitkisel kıvrımla dolgulanmış, yaprakların etrafı yeşil şeritle kuşatılmıştı ${ }^{20}$. Burada yeşil renk şeritler, kap içini kaplayan sarımsı yeşil sır üzerine uygulanmış gibi durmaktadır. Daha iyi korunmuş diğer bir çanak gövdesinde de tekrarlanan kompozisyonda, yaprak aralarına uzanan içi çapraz dolgulu sarkık üçgenlerden bir kısım korunmuştur (G. 3).

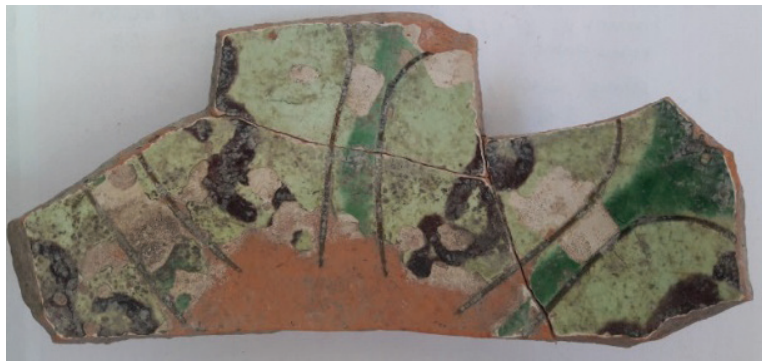

G. 3. B1.1.Yeşil ve Erguvan Lekeli, Ağız Kenarı ve Gövde Parçası (Amorium kazı arşivi)

T.10: 2'deki parçada da benzer bezeme izlenmekle birlikte eksik olan kısımlarda yaprak içlerinin benek/damlalarla dolgulu olma ihtimali de vardır ${ }^{21}$. T.10: 3 ve G.

20 Benzer kompozisyonun korunan bir kısmına sahip Ephesos-Artemision'dan ağız kenarı için bkz. BöhlendorfArslan, Die Glasierte Byzantinische Keramik aus der Turkei, Teil. III, Taf. 127 (581).

21 Form ve bezeme kompozisyonu benzer Amorium Yukarı Şehir kazı buluntuları (TT-UU tabaka) için bkz. Böhlendorf-Arslan, Die Glasierte Byzantinische Keramik aus der Turkei, Taf. 108. (435); Taf. 109 (438); Taf.110 (442-445); muhtemel benzer kompozisyona ait Ephesos-Artemision'dan alt gövde parçaları için bkz. Taf. 127 (583, 584); Pergamon buluntuları için bkz. Jean Michel Spieser, Die Byzantinische Keramik Aus der Stadtgrabung von Pergamon (Berlin: Walter de Gruyter, 1996), Taf. 53 (507); aynı mal grubundan diğer buluntular için Taf. 53 (508, 511), Taf. 54; Sevinç Gök Gürhan, "1995-2009 Yılları Arasında Ortaya Çıkarılan Seramiklerin Değerlendirilmesi," Sanat Tarihi Dergisi 18/2 (2011), 57, Tab. 7 içinde; Aphrodisias buluntusu için bkz. François, "Element Pour I'historie Ottomane d'Aphrodisias: la Vaiselle de Terre," 176, Pl. 17 (178); 177, T. 3 (173). 
4'deki parça çok küçüktür ve benzer kompozisyondan, yaprakları çevreleyen veya oluşturan yeşil şerit ile yaprak içini dolduran küçük damlacıklardan birkaçı korunmuştur. Damlacıklar, açık kahverengimsi renktir ${ }^{22}$. Benzer renk, ağız kenarını çevreleyen şeritler içinde de belirmiştir. Diğer şeritler siyahımsı renk almıştır²3. Sır içte çok açık yeşil, dişta daha koyu yeşildir. T.10: 1-3'deki parçalar kaideden ağız kenarına doğru açılarak şekillenmiş basit ağız kenarlı büyük kâse/çanaklardır ${ }^{24}$.

B1.2- Buluntular ağız kenarları biraz daha inceltilmiş olarak üstteki buluntu formlarına benzer çanaklar²5 (T.10: 4, 5) ile geniş tablalı büyük tabaklara aittir (T.11: 1-4). Ağız kenarlarını birbirine paralel kazıma yivler çevreler. Çok uçuk renk yeşil sırlıdırlar. B1'deki buluntulara kıyasla erguvan renk ton daha nettir. Erguvan ve yeşil ek renklendirmelerden çok az kısım korunmuştur.
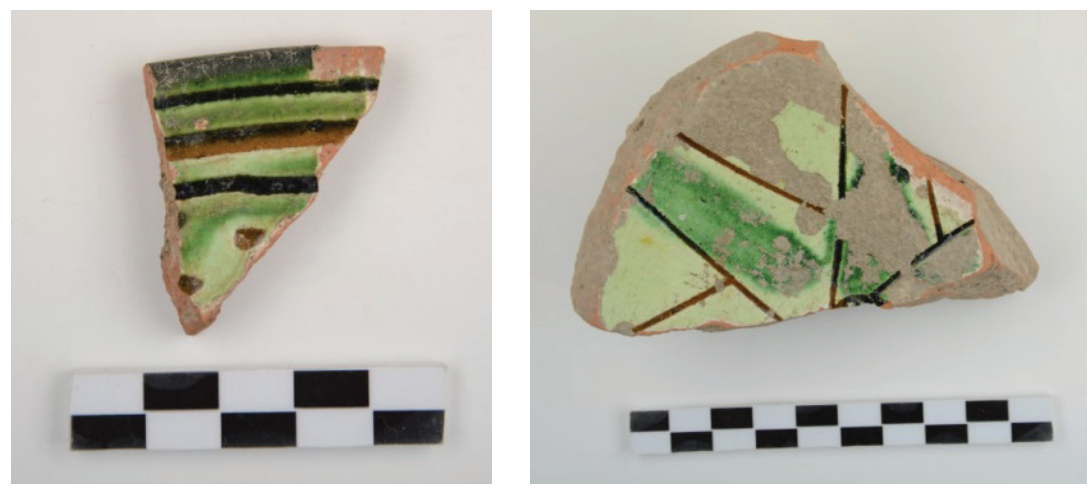

G. 4, G. 5. B1.1. ve B1.2. Yeşil ve Erguvan Lekeli, Ağız Kenarı, Kaide ve Gövde Parçası (Amorium kazı arşivi)

T.10: 4, 5'deki çok küçük parçalarda sgraffito ve erguvan renk ton korunmuştur ${ }^{26}$. D1ş yüzeylerin görünümü öncekilere benzer. T.10: 1'deki buluntunun arka yüzeyinde beliren daha koyu yeşille oluşmuş iki eğrisel hat, T.10: 5 'in arka yüzeyinde de bu kez yatay eğrisel şeklinde belirmiştir.

22 Genelde bu tip buluntularda damlacıklar farlı boyutlarda ve sıklıkta kimi zaman uzun düzensiz akmalar hâlinde erguvan rengin farlı tonlarında, kahvemsi morumsu, kahvemsi renktedir.

23 T. 9: 2’de izlendiği gibi koyu yeşil rengin kazınmış yerlerdeki görünümü siyahımsıdır. Sarımsı yeşil renk açık kahverengi, hardalımsı renk görüntüsü veriyor gibi izlenmektedir.

24 Amorium Yukarı Şehir kazısı Bizans sonrası tabakalarından (TT-UU) benzeri için bkz. Böhlendorf-Arslan, Die Glasierte Byzantinische Keramik aus der Turkei, Teil. III, Taf. 108 (435); Taf. 109 (438); EphesosArtemision'dan örnekler için bkz. Böhlendorf-Arslan, Die Glasierte Byzantinische Keramik aus der Turkei, Teil. III, Taf. 127 (581).

25 Amorium Yukarı Şehir kazısı Bizans sonrası tabakalarından (TT) benzeri için bkz. Böhlendorf-Arslan, Die Glasierte Byzantinische Keramik aus der Turkei, Teil. III, Taf. 108 (436, 437) .

26 Amorium Yukarı Şehir kazısı Bizans sonrası tabakalarından (UU) formlar benzemekle birlikte bezeli kısımdan çok az kısımları korunmuş olması nedeniyle olası benzer dekorlu parçalar için bkz. Böhlendorf-Arslan, Die Glasierte Byzantinische Keramik aus der Turkei, Teil. III, Taf. 108 (436, 437). 
Kaide parçaları da (T.11: 5, 6) bu grupla ilgilidir. T.11: 5 ve G. 5 'teki kaide tondosunda mevcut bezeme kalıntıları, T.10: 1, 2'deki kompozisyonun veya varyasyonlarının uygulandığını işaret eder. T.11: 6 ve G. 6'daki tondoda da bu gruplarda sıklıkla izlenen konsantrik daireler ortasında stilize palmetçik motifi yer almış olmalıdır.

\section{Tablo 11}

Yeşil ve Erguvan Lekeli Kaplar (L. Doğer- M. E. Armağan, 2020)

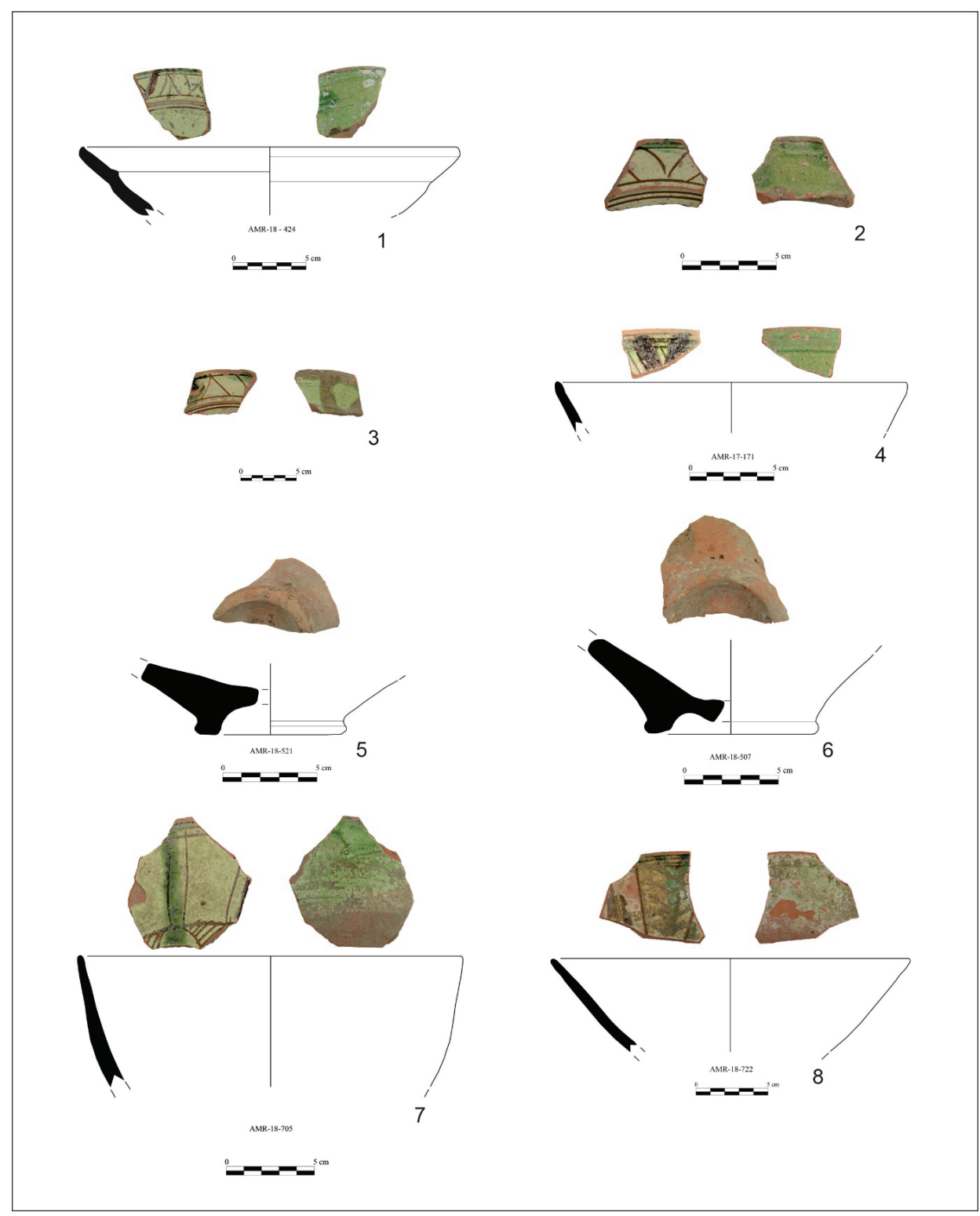



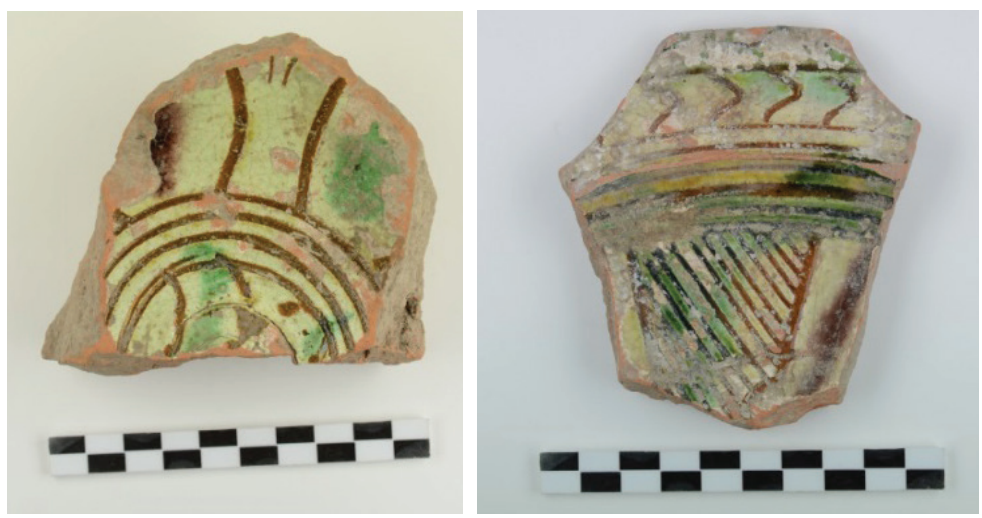

G. 6, G. 7. B1.2 ve B1.3 Yeşil ve Erguvan Lekeli, Kaide ve Gövde, Ağız Kenarı ve Gövde Parçası (Amorium kazı arşivi)

Tabak formlarının geniş ağız tablalarında da yine başka alanlardan benzer buluntularda sıkça tercih edilmiş ters yönlerde birbirine değen sivri uçlu yaprak dizisi bordürü yer alır. T.11: 7, 8'deki basit ağız kenarlı kaide ve gövde parçalarında yeşil ek renklendirmeler ile tüm gövdeyi kaplayan kompozisyondan geometrik dizaynlar az korunmuştur.

B1.3 - T.12'de yer alan ince cidarlı ağız kenarı ve gövde parçalarında ise ek renklendirmelerinden ziyade daha derin ve yoğun kazıma bezemenin göze çarptığı düzenleme gösterirler. Ana motif aralarının verev, çapraz taramalar, tabak tablalarında (T.12: 2, 3 ve G. 7) aralıklı dizilmiş şevron dizisi görülür ${ }^{27}$. Ek renkler kahverengimsi mangan ve öncekilere göre daha canlı yeşildir. Açık sarı olan sır renginden daha koyu renk sarı da lekeler de belirgin hâlde kullanılmıştır.

27 Amorium Yukarı Şehir kazısı Bizans sonrası tabakalarından (UU), form ve bezeme olarak benzer buluntu için bkz. Böhlendorf-Arslan, Die Glasierte Byzantinische Keramik aus der Turkei, Teil. III, Taf. 109 (440). 


\section{Tablo 12}

Yeşil ve Erguvan Lekeli Kaplar (L. Doğer- M. E. Armağan, 2020)

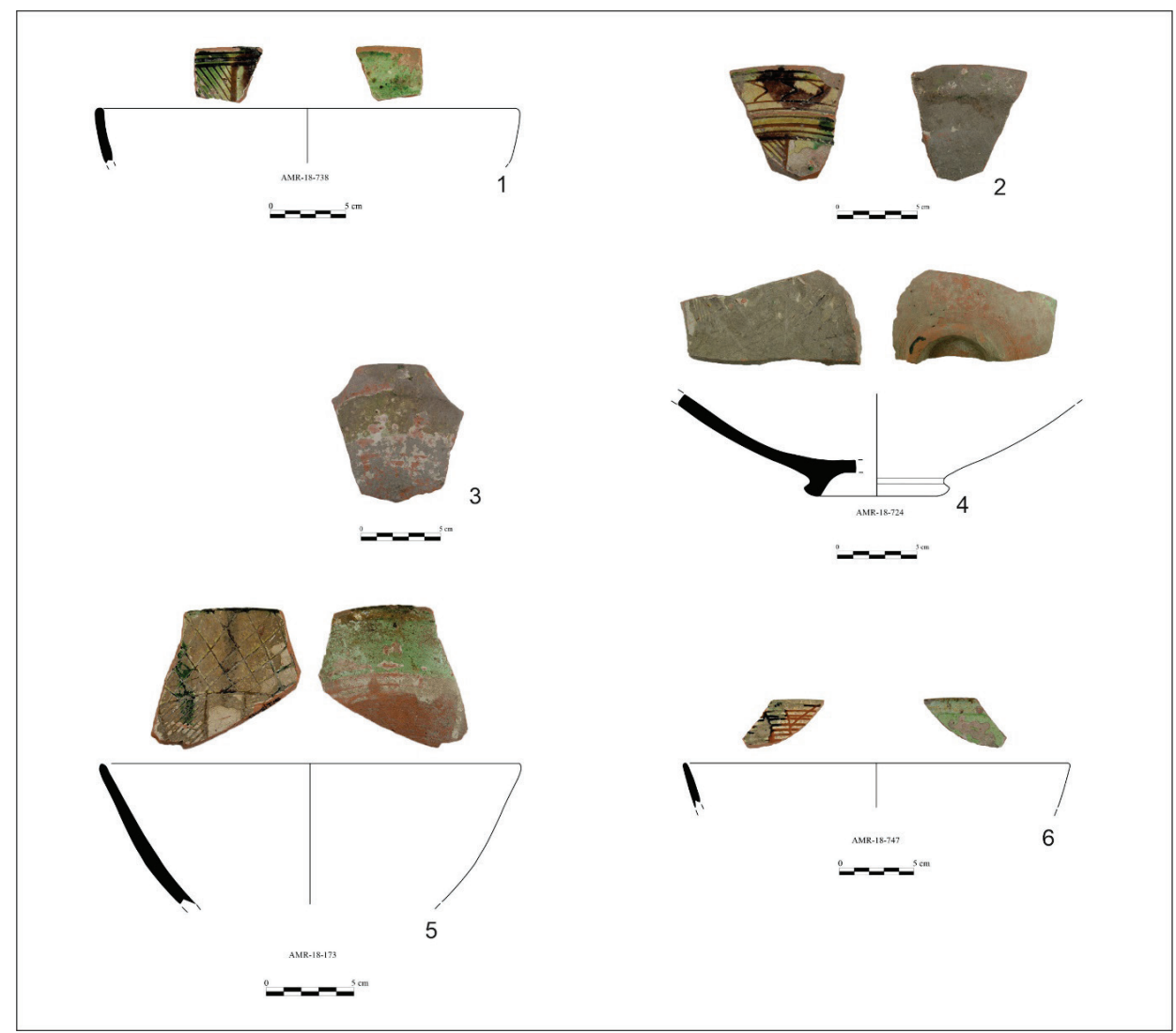

B1.4- T.13 ve 14'deki olasılıkla kâse, büyük tabak ağız kenarı ve gövde parçaları ile kaide parçaları da, bezemelerin kalın kazımalı hardal renk görünümlü konturları, net görüntü vermeyen sır, bulanık kabaca uygulanmış ek renklendirmeleri ile birbirine benzer görüntü oluştururlar. Bezemelerin çoğu aşınmıştır ancak kompozisyonu oluşturan iri spirallerin (T.13: 1), verev taramaların (T.13: 2), dikey paralel taramalı bordürün (T.13: 3) bir kısmı korunmuştur. 


\section{Tablo 13}

Yeşil ve Erguvan Lekeli Kaplar (L. Doğer-M. E. Armağan, 2020)
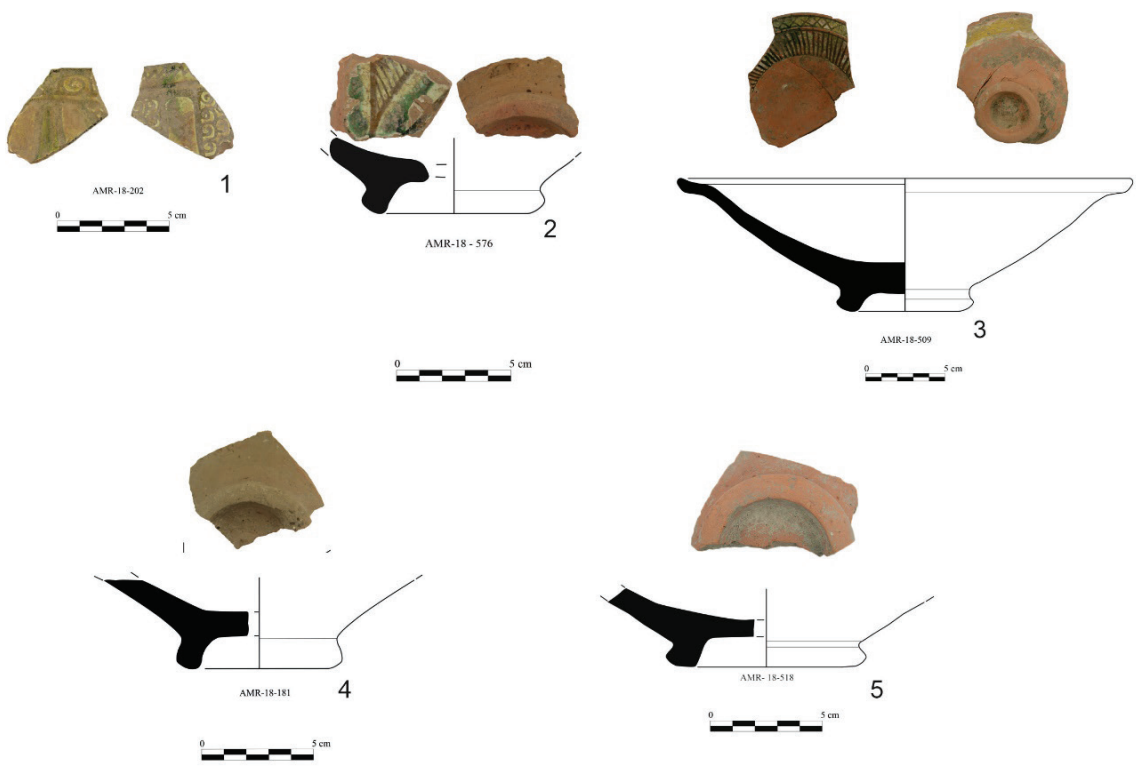

\section{Tablo 14}

Çok Renkli Sgraffito Seramikler (L. Doğer- M. E. Armağan, 2020)
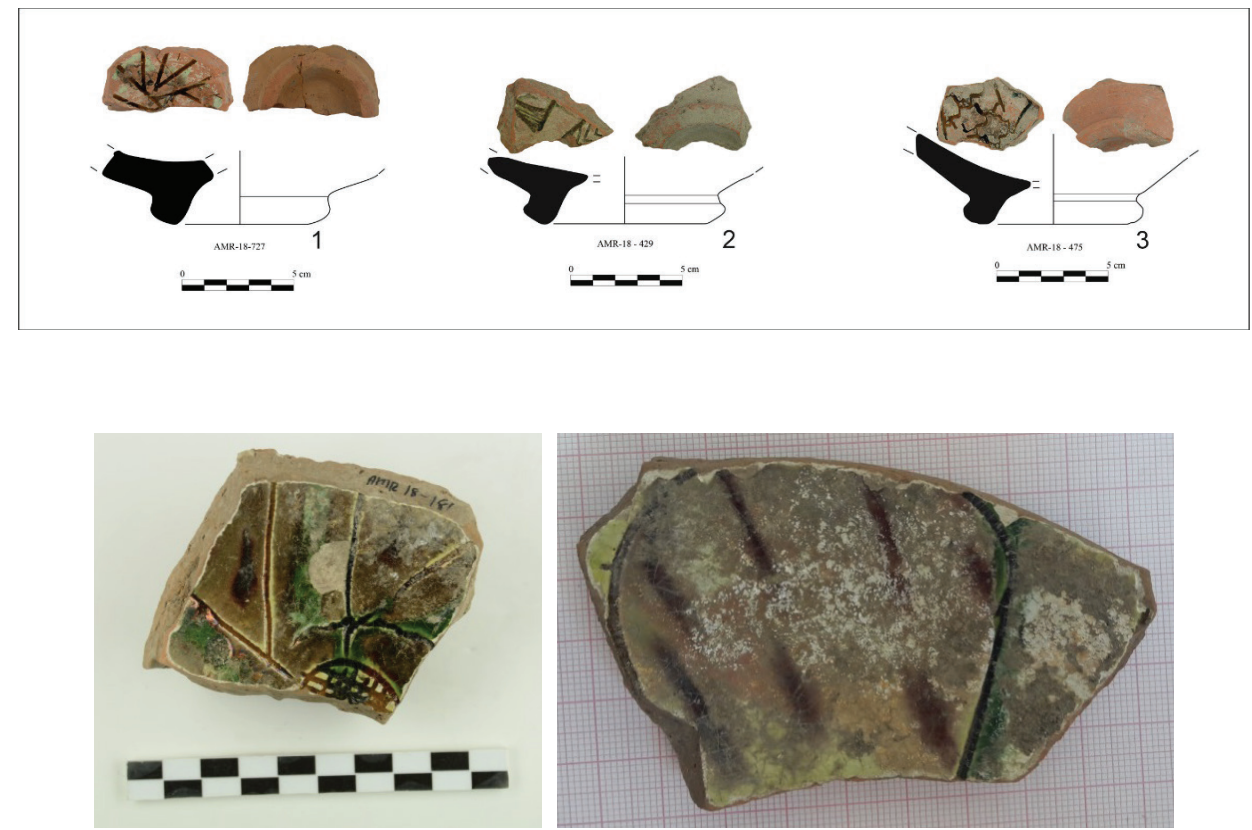

G. 8, G. 9. B1.4. Yeşil ve Erguvan Lekeli, Kaide ve Gövde Parçası, Amorf Gövde Parçası (Amorium kazı arşivi) 
T.13: 4 ve G.8'deki tondoda içi çapraz taralı daire yer alır. Tüm kabı kaplayan iri yapraklar buradan dağılır. Az kısmı korunmuş kompozisyon, T.10: 1-3'dekilerin de sahip olduğu kompozisyonun bir yorumu olmalıdır ${ }^{28}$. G. 9'daki gövde parçasındaki bezeme de bu buluntularla ilintilidir. Boşlukları filizli dalları temsilen iri spirallerle dolgulanmış, ortada taç yapraklardan oluşmuş iri bir rozet çiçek motifi de bu tip seramiklerin repertuvarıdı2 ${ }^{29}$ (T.13: 5 ve G. 10).

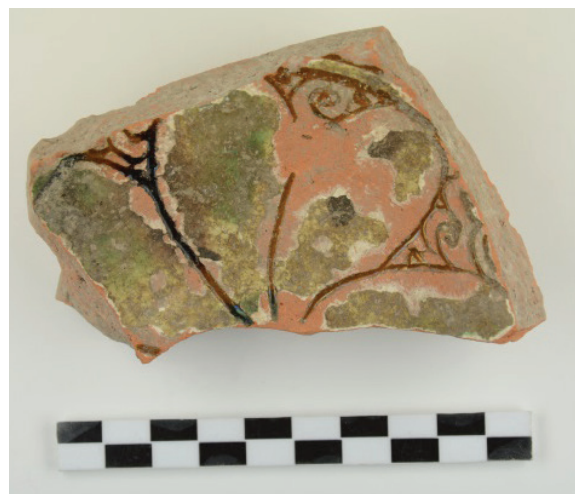

G. 10. B1.4. Yeşil ve Erguvan Lekeli, Kaide ve Gövde Parçası (Amorium kazı arşivi)

\section{Sıraltı Boya Teknikli Milet Tipi Seramikler (T. 9: 2)}

İS-11 açması +976.63 m kodundan ele geçmiş, $24.0 \mathrm{~cm}$ çapındaki bir derin kâse veya çanak parçalar ${ }^{30}$; içte şeffaf renksiz sır altına uygulanmış mavimsi renk bezek taşır. Üst kısmı yuvarlak, alt kısmı sivri sonlanan firça darbesi ile yapılmış yaprak dizileri ağız kenarını çevrelerken, karşılıklı dizilmiş olarak gövdede dikey uzanır. Dış yüzey parlak yeşil renk sırlıdır. Ağız kenarından gövdeye geçişten itibaren ince yiv sıralarının ortasına yatay eksende parmak baskı dizisi uygulanmıştır (G. 11). Parça 5 YR 5/6 sarımsı kırmızı renk B tipi hamur gösterir.

28 Az farklı benzeri için bk. Amorium Yukarı Şehir Bizans sonrası tabakalarından (TT) benzeri için bkz. Böhlendorf-Arslan, Die Glasierte Byzantinische Keramik aus der Turkei, Teil.III, Taf.108 (435).

29 Eskişehir Karacahisar Kalesi ve Midaion Höyük’ten benzerleri için bkz. Bursalı, "Eskişehir Karacahisar Kalesi Sgraffito Dekorlu Ortaçağ Seramikleri,” Levha 66; merkezi T.10:'deki gibi olmak üzere bu motifin daha fazla yapraklı yorumu için Ephesos-Artemision'dan bkz. Böhlendorf-Arslan, Die Glasierte Byzantinische Keramik aus der Turkei, Teil. III, Taf. 127 (586).

30 Benzer form için bkz. Gülgün Yılmaz, Edirne Müzesi Osmanlı Seramikleri (Edirne: Trakya Kalkınma Ajansı Yayınlar1, 2012), 44, Kat.no.A2.04;93, Kat.no.A2.53;100, Kat.no.A2.60; ayrıca İstanbul (Saraçhane), İznik, Bursa, Balıkesir, Altınova'dan örneklerle bu tip form için bkz. Turgay Polat, "Milet İşi Seramiklerde Form Tipolojisi Üzerine Bir Deneme," Sanat Tarihi Dergisi XXV/2 (2016), 225, Tab.3. 


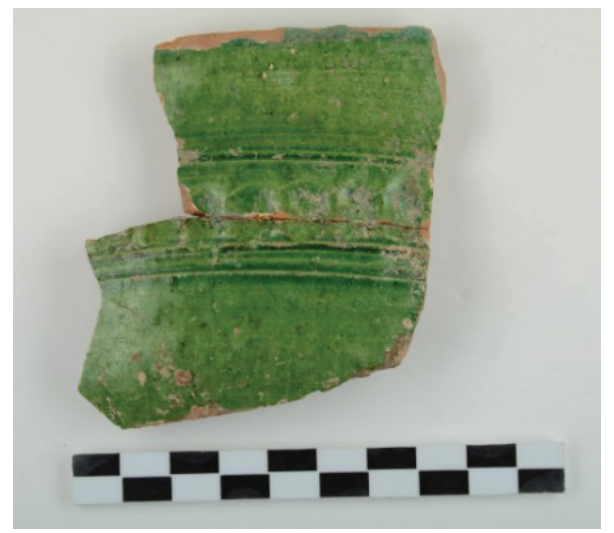

G. 11. Milet Tipi Kâse, Ağız Kenarı ve Gövde Parçaları-dış yüzey (Amorium kazı arşivi)

\section{Sıraltı Astar Boyama (Slip) Teknikli Seramikler (T. 15)}

İS-5 açmasından basit ağız kenarlı bir kâse parçası ${ }^{31}$ İS-9' dan ve tanımsız alandan, çapları $23.0 \mathrm{~cm}$ ve $27.0 \mathrm{~cm}$ olan iki büyük tabak parçası ele geçmiştir. A tipi, kırmızımsı sarı tonlarında hamur yapısı gösterirler. Bezemeler şeffaf açık sarı, hafif yeşilimsi sarı sır altındadır. T.15: 1, 2, 3'deki ağız kenarının dış yüzeyinde B2-B3 gruplarında (T. 11-12) görülenlere benzer beyaz astarlı renk yeşil sır yer alır. T.15: 5 'teki buluntuda ise A3, A4, A5 gruplarında da görülen pembemsi krem astar kullanılmıştır. Sır sarımsı zeytin yeşili görünümdedir (T.15: 4).

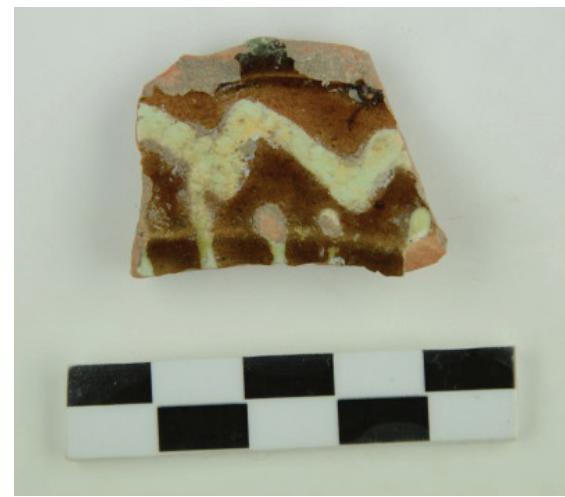

G. 12. B1.1. Astar Bezemeli, Ağız Kenarı Parçası (Amorium kazı arşivi)

Beyaz astarla yapılan bezemelerden çok az kısımlar korunmuştur. Ağız kenarından gövdeye doğru inen doğrular (T.15: 1), yatayda dolanan bitkisel motife atfen stilize kıvrımlar (T.15: 2, 3) ve zikzakların (T.15: 4 ve G. 12) bir kısmı mevcuttur. İç yüzeylerde astar bezeme dişındaki yüzey hamur rengine göre, kahverengi (T.15: 4) veya

31 Astar bezemesi tam korunmamış olmakla birlikte Amorium Yukarı Şehir Bizans sonrası tabakalarından (UU), form olarak benzeri için bkz. Böhlendorf-Arslan, Die Glasierte Byzantinische Keramik aus der Turkei, Teil. III, Taf. 106 (427), ağız kenarı dıştan incelmiş bir diğer parça için Taf.107 (428). 
açık kahve, hardalımsı sarı renk almıştır² ${ }^{32}$ T.15: 8'deki düz dipli gövde parçası aynı yerde ele geçmiş kalın cidarlı içe çekik ağızlı tiplere (T.15: 4) ait olabilir.

\section{Tablo 15}

Siraltı Astar Bezeli Seramikler (L. Doğer- M. E. Armağan, 2020)

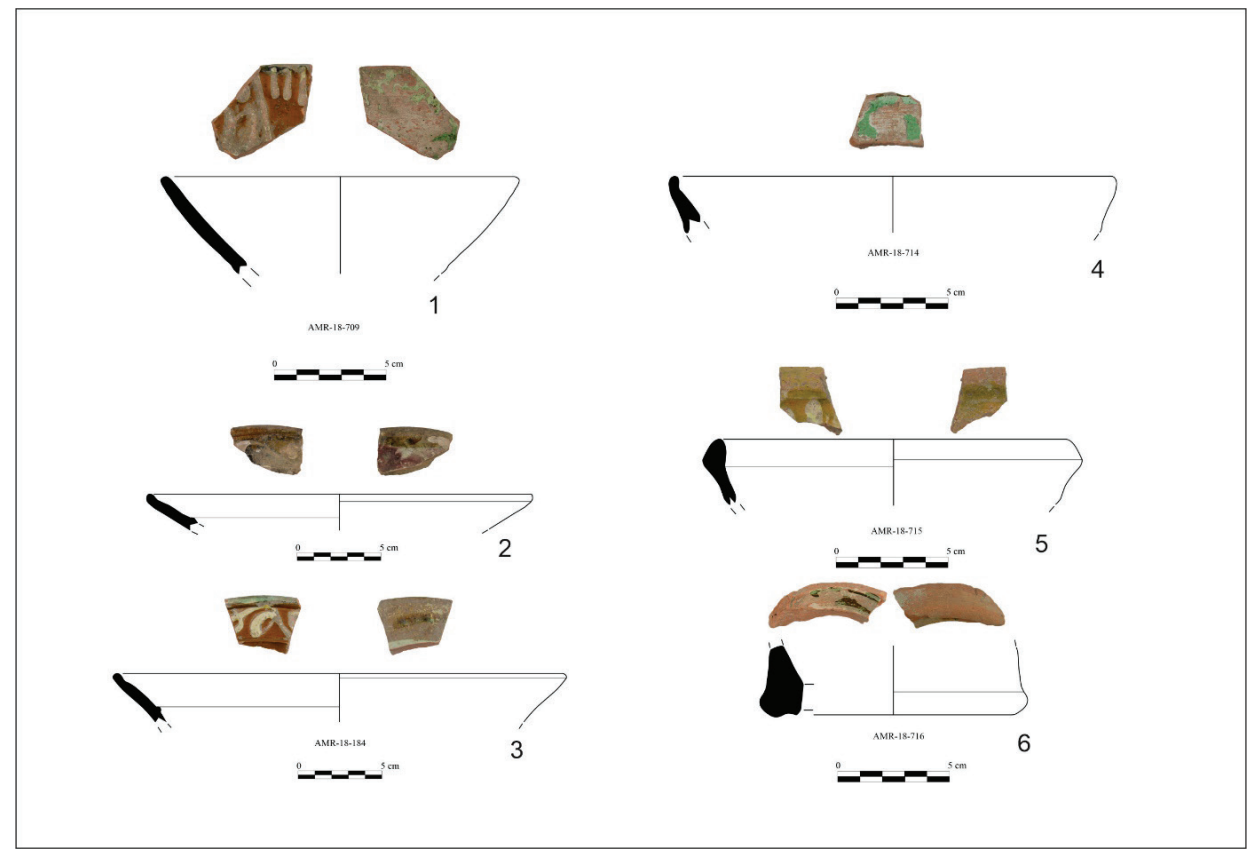

\section{Diğer Seramik Buluntular (T. 16)}

Astar ve sırları, bezemelerinden çok azı korunmuş bazı parçalar mevcuttur. Bunlardan biri A tipi hamur yapısı gösteren, yeşil sır izleri mevcut ağzı süzgeçli kapalı kap parçasıdır (T.16: 1). Bir diğeri $7.0 \mathrm{~cm}$ düz dipli yeşil sır izleri taşıyan gövde parçasıdır (T.16: 2). Açık kaplar ise kâse ve çanaklara aittir (T.16: 3-5).

32 Formlar benzemekle birlikte, bezeli kısımdan çok az kısımlar korunmuş olması nedeniyle olası benzer dekorlu parçalar için bkz. Amorium Yukarı Şehir kazısı Bizans sonrası tabakalarından (UU) benzeri için bkz. Böhlendorf-Arslan, Die Glasierte Byzantinische Keramik aus der Turkei, Teil. III, Taf. 108 (436, 437). 


\section{Tablo 16}

Diğer Seramik Buluntular (L. Doğer- M. E. Armağan, 2020)

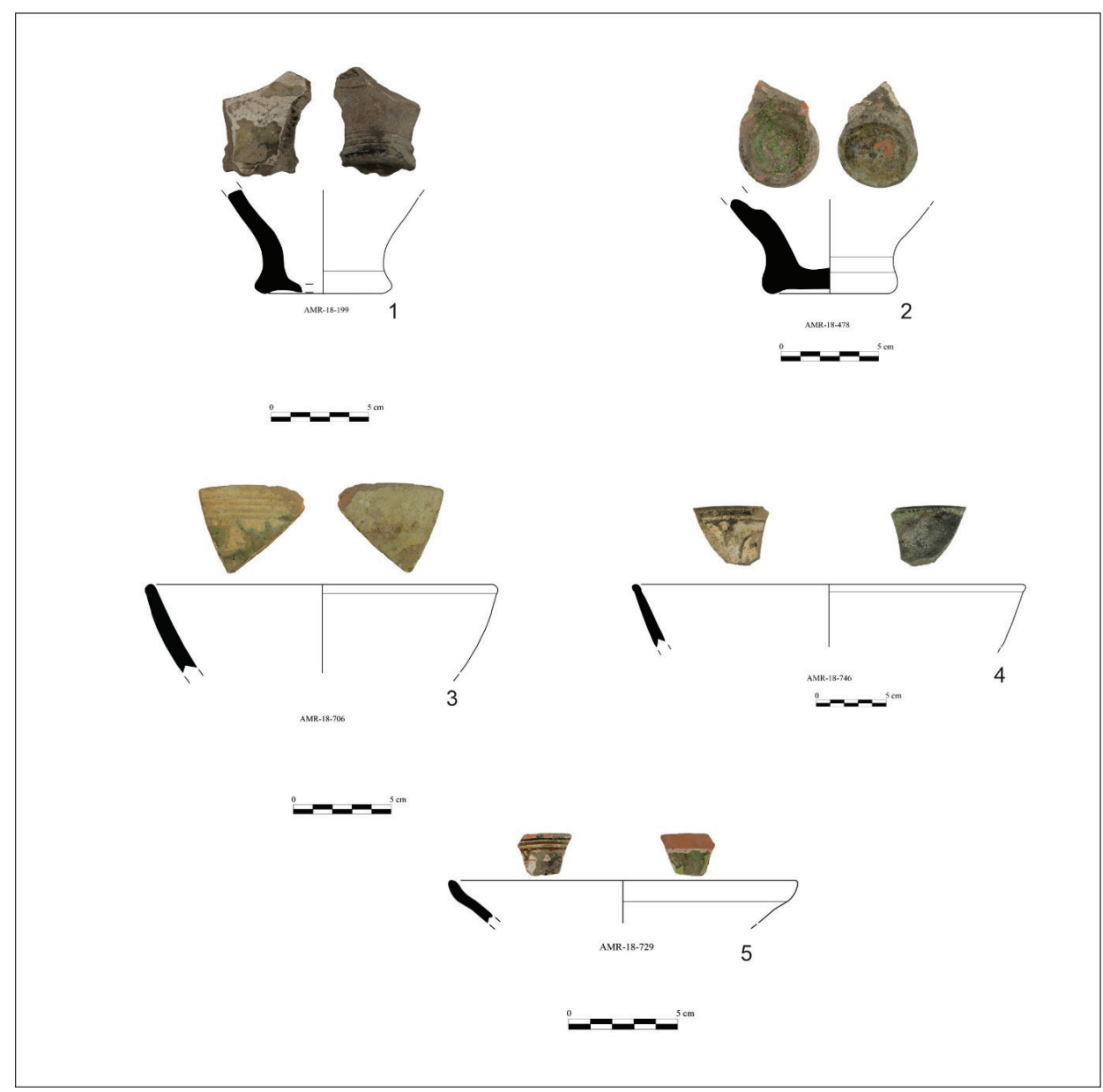

\section{Değerlendirme}

Açma numara ve seviyelerine göre toplanan seramik buluntuların etütleri, her bir açmanın yaklaşık aynı seviyesinde birbirleriyle ilintili gruplar olduğunu göstermiştir. Ancak parçaların genelde çok küçük olması, korunmuş olan kısımların verdiği bilgilerle yetinmeyi zorunlu kılar. Bu bağlamda Amorium’da da çok renkli sgraffito içeriğinde ele alınan Yeşil ve Erguvan Lekeli buluntular daha yol gösterici nitelik taşır. En yoğun buluntu grubunu tek renk şeffaf yeşil sırlı kaplar, en azını turkuaz renkliler oluşturur.

Şeffaf yeşil renk sır, çağlar boyu en fazla uygulamaya konulan renktir. Batı Anadolu kazı buluntularından hareketle MÖ. 1. yüzyıl-MS. 1. yüzyıla ait seramiklerde izlediğimiz yeşil sır, uzun bir aradan sonra MS. 7. yüzyıldan itibaren Bizans dünya- 
sında yaygınlaşarak günümüze değin kullanılagelmiştir. Bu nedenle ayırt edici başka tespitler olmadıkça tasnifi zordur. Yeşil sırlı seramiklerin daha belirgin gruplarla ele geçiriliş durumları, hamur, form, teknik ilintileri ile kronolojik olarak fikir verir.

Yeşil ve Erguvan Lekeli, Yeşil ve Mor Lekeli Yağlı Mal, Eflatun/Erguvan-Kahverengi Lekeli olarak da tanımlanan aynı türden buluntular başta Amorium Yukarı Şehir kazısı olmak üzere, Orta Anadolu'da Eskişehir Karacahisar Kalesi kazısı, yayınlanmamış olarak bildirilen Kotyaion, Midaion, Kanlıtaş Höyük (Eskişehir/İnönüKütahya sınırında Kuzfındık Köyü) ve Kilistra (Konya/Gökyurt) yerleşimlerinden ${ }^{33}$, Batı Anadolu'da henüz yayınlanmamış olarak İzmir Kadifekale kazısı; Ephesos'da Ayasuluk Tepesi, Artemision kazıları, Pergamon, $\operatorname{Sardis}^{34}$, Aphrodisias ${ }^{35}$, Hierapolis ${ }^{36}$, Miletos $^{37}$ kazılarından ele geçmiş, Ilion/Troas' ${ }^{38}$ ulaşmış olduğu tespit edilmiştir.

Çağdaş olarak Balat İlyas Bey Külliyesi araştırmalarından ${ }^{39}$, yerel üretim olarak Ephesos Türbe kazılar1 ${ }^{40}$, Manisa Gülgün Hatun Hamamı'ndan ${ }^{41}$ tek renkli seramiklerin yanı sıra, çok renkli sgraffito tekniğinde buluntular ele geçmiştir. Yine aynı yerden içi tek renk yeşil sırlı, dış yüzeyi eflatun ve açık yeşil ek renk bezeli iki buluntu her iki türün birlikteliği açısından ayrıca anlamlı olmuştur ${ }^{42}$. Ancak bunlar Amorium buluntularından en azından renk skalası, bezeme repertuvarı olarak daha farklı bir ekol gösterirler. İşçilik daha ince bitkisel karakter natüralist olarak daha belirgindir.

33 Öztaşkın, "Eskişehir Karacahisar Kalesi Ortaçağ Seramiklerinden Bir Grup: Yeşil ve Erguvan Lekeli Seramikleri," 531.

34 Howard G. Crane, "Preliminary Observations on the Glazed Pottery of the Turkish of the Period from Sardis," C. H. Greenewalt Jr., The Eighteenth Campaign at Sardis, Bulletin of the American Schools of Oriental Research 228 (1977), 53. Abb.7.

35 Muradiye Öztaşkın, "Byzantine and Turkish Glazed Pottery Finds from Aphrodisias," Поливная Керамика Средиземноморья И Причерноморья X-XVIII вв, с. 2, Еd. С. Г. Бочарова, В. Франсуа ve А. Г. Ситдикова, (Kazan-Kishinev: Издательство «Stratum plus» P.Р.,Университет «Высшая антропологическая школа» 2017), 175.

36 Paul Arthur, Bizans ve Türk Dönemi’nde Hierapolis (Pamukkale) (İstanbul: Ege Yayınları, 2006), 87, res.33.

37 Böhlendorf-Arslan, Die Glasierte Byzantinische Keramik aus der Turkei, Taf. 130 (773).

38 Böhlendorf-Arslan, Die Glasierte Byzantinische Keramik aus der Turkei, Taf. 87 (276).

39 Buluntular için bkz. Sevinç Gök-Gürhan, Bir Seramik Definesinin Öyküsü, Saruhan Beyliği'nin Mirası: Manisa Gülgün Hatun Hamamı Seramikleri (Manisa: Manisa Belediyesi, 2011), 306, Tab.4.

40 Buluntular için bkz. Joanita Vroom ve Ebru Fındık, "The Pottery Finds," Die Türbe im Artemision Ein frühosmanischer Grabbau in Ayasuluk/Selçuk und sein kulturhistorisches Umfeld, Österreichisches Archäologisches Institut Sonderschriften 53 (Wien: Gesamtherstellung. Holzhausen Druck GmbH, 2015), 221, Pl.10; Joanita Vroom, "Bright Finds, Big City: Medieval Ceramics from Old and Recent Excavations in Ephesus (Turkey)," XIth Congress AIECM3 on Medieval and Modern Period Mediterranean Ceramics, Proceedings, I, (Ankara: Koç University Vehbi Koç Ankara Araştırmaları Uygulama ve Araştırma Merkezi, 2018), 388, Kat.13,14; Analitik araştırma için bkz. Sylvie Yona Waksman ve M. M. Carytsiotis, "Medieval Ceramics from the Türbe: an Archaeometric Viewpoint," Die Türbe im Artemision Ein frühosmanischer Grabbau in Ayasuluk/ Selçuk und sein kulturhistorisches Umfeld, Österreichisches Archäologisches Institut Sonderschriften 53 (Wien:Gesamtherstellung. Holzhausen Druck GmbH, 2015), 30, 309, Pl.3.

41 Buluntular için bkz. Sevinç Gök Gürhan, "Beylikler Dönemine Ait Sgraffito Teknikli ve Tek Renk Sırlı Kaplar (Manisa Gülgün Hatun Hamamı Buluntuları)," Sanat Tarihi Dergisi XVII/2 (2010), 74-76, Tab.1-3; Gök Gürhan, Bir Seramik Definesinin Öyküsü, Saruhan Beyliği'nin Mirası: Manisa Gülgün Hatun Hamamı Seramikleri, 36, 38; Fot.17-20.

42 Buluntular için bkz. Gök Gürhan, "Beylikler Dönemine Ait Sgraffito Teknikli ve Tek Renk Sırlı Kaplar (Manisa Gülgün Hatun Hamamı Buluntular1)," 76, Tab.3, Kat.20,21. 
Ephesos'da Ayasuluk Tepesi Aziz Ioannes Kilisesi Atrium kazısından 14.-15. yüzy1l yerel üretim olarak tanıtılan çok renkli sgraffito buluntularında renk kullanımı ve işçiliği farklı görülmektedir ${ }^{43}$. İzmir, Kemalpaşa Nif (Olympos) Başpınar Kilisesi ${ }^{44}$ ile Nif Laskarisler Sarayı kazılarından da birkaç parça çok renkli sgraffito parça ele geçmiştir. Bunların biri T.11: 1, 2’dekilere benzeyen ağız kenarı form ve bezemesi taşıyan ağız kenarıdır ${ }^{45}$; ancak üretim ve dağılımları konusunda fikir için veriler yetersizdir. Koyu sarı ve canlı yeşil ek renkle zenginleştirilmiş İznik üretimi bazı buluntularda da benzer motiflerin tercih edildiği gözlenir ${ }^{46}$.

Pergamon buluntularının elemental hamur analizleri, tek renk sırlı ve lekeli seramiklerin aynı üretim grubuna dâhil olduğunu kanıtlamıştır ${ }^{47}$. Eskişehir, Karacahisar Kalesi'nden ele geçen Yeşil ve Erguvan Lekeli Seramiklerle aralarında Yeşil Sırlı Sgrafitto seramiklerin de bulunduğu diğer seramik gruplarıyla benzerlikler tespit edilmiştir $^{48}$. Literatürde Yeşil ve Mor Lekeli Yağlı Mal olarak da tanımlanan buluntularla aynı hamur yapısında, bezemesiz tek yeşil sırlı parçalar da 'Yağlı Mal' başlığı altında incelenmiştir ${ }^{49}$. Pergamon ve Sardis’te ele geçen örneklerin analizlerle aynı üretim grubu olduğu tespit edilmiştir ${ }^{50}$. Karacahisar Kalesi buluntuları arasında da tek renk

43 Buluntular için bkz. Gülgün Yılmaz, "St. Jean (Aziz Yuhanna) Kilisesi Atrium Kazılarında Bulunan Seramik Eserler," Mustafa Büyükkolancı' ya Armağan (İstanbul: Ege Yayınları, 2015), 773, Kat.no.3.1, Kat.no.3.2, Kat. no.3.2'deki kâsenin bezemesinde sadece şeritler hâlinde eflatun/morumsu renk ek boya kullanılmıştır. Ana bezeme motifleri dışındaki alanları dolgulayan derin kazınmış spiraller, karşılıklı kademeli kümeler hâlinde çakışan tarama kümeleri karakteristik görünüm verir ve benzerleri açık kapalı kap buluntuları olarak Kuşadası, Kadıkalesi (Anaia) kazılarında da bulunmuştur. Kontekstsiz buluntu olan Anaia kapları ilk yayına girdiğinde geç 12.-13. yüzyıllara tarihlenmiş olup şimdiki bilgilerimizle 14. yüzyıla ait görülürler. Anaia için bkz. Lale Doğer, “Anaia-Kuşadası Kadıkalesi Kazısı 2002 Yı1ı Bizans Dönemi Seramik Buluntuların Ön Değerlendirmesi,” Sanat Tarihi Dergisi Aydoğan Demir'e Armağan XIII/I (2004), 30, Res.13; Zeynep Mercangöz ve Lale Doğer, "Kuşadası, Kadıkalesi/Anaia Bizans Sırlı Seramikleri,” I. Arkeometri Çalıştayl, Türkiye Arkeolojisi'nde Seramik ve Arkeometrik Çalışmalar 7-9 Mayıs 2009 (Ankara: ODTÜ Yayınları, 2009), 96, Res.11.

44 Lale Doğer, "Late Byzantine And Ottoman Pottery From Nif-Olympus," The Second International Conference on the Archaeology of Ionia, Landscapes of Ionia: Towns in Transition, May 30-June 2, 2011, Izmir - Turkey. Recent Studies on the Archaeology of Anatolia (Oxford: BAR Internetional Series 2750, 2015), 66, P1.X (52, 53).

45 Zeynep Mercangöz, Zafer Derin ve Lale Doğer, "Kemalpaşa, Laskarisler Sarayı,” Ege Üniversitesi Arkeoloji Kazılarl (İzmir: Ege Üniversitesi, 2012), 448, T.6. Bu tür form ve bezeme, dekorasyon tekniği 13.-14. yüzyıl Anadolu'da seramik üretiminin de olduğu Korucutepe, Hasankeyf'de ele geçen İslam seramikleri için bkz. Ömür Bakırer, "The Medieval Pottery and Baked Clay," Korucutepe (Amsterdam: Nort-Holland Publishing Company, 1980), 3: 189-249, pl. 65-113, form. C26, 27, 28; bezeme. C6, 29, 20; 28, B71, R26; Nurşen Özkul Fındık, “Artuklu-Eyyubi Dönemlerinde Hasankeyf’te Seramik Atölyeleri ve Üretimleri,” Hacettepe Üniversitesi Edebiyat Fakültesi Dergisi 30/2 (2013), 57, Fot.13, 14; Doğu Akdeniz’in Haçlı (BöhlendorfArslan, Die Glasierte Byzantinische Keramik aus der Turkei, Teil. III, Taf. 165 (893) ve ile Kibris seramikleri (D. Papanikola Bakirtzi, F. N. Mavrikiou ve Ch. Bakirtzi, Byzantine Glazed Pottery in the Benaki Museum (Athens: The Museum, 1999) 163, Kat.337 ile Yakındoğu'da Suriye, Irak seramiklerinde de görülür.

46 İznik Tiyatro kazısından buluntu için bkz. Özkul Fındık, İzikik Roma Tiyatrosu Kazısı Buluntuları (19801995) Arasındaki Osmanlı Seramikleri (Ankara: T.C. Kültür Bakanlığı Yayınları, 2001), 96, Fot.96, 97; 92, Fot.83 (astarlı-kazımalı olarak yarı mamul).

47 Analiz için bkz. Waksman ve Spieser, "Byzantine Ceramics Excavated in Pergamon: Archaeological Classification and Characterization of the Local and Imported Productions by PIXE and INAA Elemental Analysis, Mineralogy and Petrography," 123.

48 Daha geniş bilgi için bkz. Öztaşkın, "Eskişehir Karacahisar Kalesi Ortaçağ Seramiklerinden Bir Grup: Yeşil ve Erguvan Lekeli Seramikleri," 530.

49 Böhlendorf-Arslan, Die Glasierte Byzantinische Keramik aus der Turkei, 149-150.

50 Öztaşkın, "Eskişehir Karacahisar Kalesi Ortaçağ Seramiklerinden Bir Grup: Yeşil ve Erguvan Lekeli Sera- 
farklı tonlarda yeşil sırlı kaplar ile çok renkli sgraffito buluntuların yağlı mal tabir edilen hamur yapısı gösterdikleri bildirilmiştir ${ }^{51}$.

\section{Ephesos Artemision'dan Eflatun/Erguvan-Kahverengi Lekeli olarak tanımlanan} çok renkli sgraffito seramikler de minerolojik/ petrografik analizle yerel üretim olarak belirlenmiştir. İki farklı hamur yapısı ile tek renk yeşil sırlı ve turkuaz-mavi sırlı seramikler de yerel üretim olarak tanıtılmışıır ${ }^{52}$.

Pergamon'daki kazılar, seramikleri Hristiyan nüfus ile Türk Beyliğinin ortak kullandığı bir üretim grubu olarak yönlendirmiştir ${ }^{53}$ ve 1350-1375 arasına tarihlendirilmişlerdir ${ }^{54}$. Hierapolis'ten ele geçen bazı yeşil ve erguvan lekeli seramik parçalar 14. yüzyıla tarihlenmiştir ${ }^{55}$. Aphrodisias Güney Agora ve Kuzey Cadde kazılarından ele geçen üçayak ve yarı mamul bir parça ile Beylikler Dönemi çok renkli sgraffito üretimine ilişkin veri sunulmaktadır ${ }^{56}$. Miletos'ta bu dönemde yoğun mikalı hamurlu bezemeli, bezemesiz tek renk sırlı ve çok renkli sgraffitonun varyantlarında üretim tespit edilmiştir ${ }^{57}$. Ancak buradaki bazı buluntular hamur, form ve ek renkteki farkl1lıklarla Yeşil ve Erguvan Lekeli Seramiklerden farklı görülmüştür ${ }^{58}$. Ayasuluk kazılarından da bezeme tekniği ve kompozisyon bakımından benzerliklere karşın renk tonlarının farklı olduğu buluntu vardır ${ }^{59}$. İznik’te başta Çini Fırınları ve Roma Tiyat-

mikleri," 531; Sardis için bkz. Jane Eyer Scott ve Diane C. Kamilli, "Late Byzantine Glazed Pottery from Sardis," XV ACIEB, Athenes, Septembre 1976, II, (Athenes: Art et Archéologie B,1981) 686, 687.

51 Öztaşkın, "Eskişehir Karacahisar Kalesi Ortaçağ Seramiklerinden Bir Grup: Yeşil ve Erguvan Lekeli Seramikleri," 528.

52 Vroom, "Medieval Pottery from the Artemision in Ephesos: Imports and locally produced wares," 27, $30,32$.

53 Spieser, Die Byzantinische Keramik Aus der Stadtgrabung von Pergamon, 49-50.

54 Beate Böhlendorf-Arslan, "Die Beziehungen zwischen byzantinischer und emiratszeitlicher Keramik," Ortaçağ 'da Anadolu, Prof. Dr. Aynur Durukan'a Armağan (Ankara: Hacettepe Üniversitesi Edebiyat Fakültesi, 2002) 147-148, 150; Taf.189 (7).

55 Arthur, Bizans ve Türk Dönemi’nde Hierapolis (Pamukkale), 87, res. 33.

56 Öztaşkın, "Byzantine and Turkish Glazed Pottery Finds from Aphrodisias," 179, P1.7 (8,9).

57 Miletos Piskoposluk Sarayı kazısında, 0206-0208, 0308, 0410 ve 0605 kontekstlerinden hareketle 14.-15. yüzy1l Beylikler Dönemine tarihlendirilen Çok Renkli Sgraffito seramikler için bkz. Philipp Niewöhner, "Der Bischofspalast von Milet," Archaologischer Anzeiger 2015/2 (2016), 251, dipnot 337, fig.100, 252.

58 Beate Böhlendorf-Arslan, "Stratifield Byzantine Pottery from the City Wall in the Southwestern Sector of Amorium," Çanak, Arkeolojik Kazılarda Ele Geçen Geç Antik, Bizans, Selçuklu ve Osmanlı Seramiği ve Mimari Seramiği (Çanakkale, 1-3 Haziran 2005) Bildiri Kitabı Byzas 7 (İstanbul: Ege Yayınlar1, 2007), 91, 92. Ek renklendirmede, yeşil, yeşil ve kavuniçi, yeşil-kahverengi kombinasyonları kullanılmıştır. Hamur analizleri ile yerel üretim "Anaia Malı” olarak tanımlanan 13. yüzyıl kapları da yeşil ve kavuniçi ek renklendirmeli sgraffito teknikle bezelidir. Tek renk sırlı bezemeli veya sgraffito bezeli üretimlerin (önceki yayınlarda Zeuksippus Ailesi I olarak tanımlanan), bezeme olarak diğer bir varyasyonlarıdır. İnce cidarları ile parlak renkleri ile de geçiş veya Beylikler Döneminin aynı renkleri taşıyan çok renkli üretimlerinden farklıdırlar. Anaia için bkz. Sylvie Yona Waksman, "The Identification and Diffusion of Anaia's Ceramic Products: A Preliminary Approach Using Chemical Analysis," Byzantine Craftsmen-Latin Patrons, Reflections from the Anaian Commercial Production in the Light of the Excavations at Kadıkalesi nearby Kuşadası (İstanbul: Ege Yayınları, 2013), 104, Fig. V-1 (BYZ 349, 350).

59 Beylikler Dönemine tarihli kaide ve gövde parçası için bkz. Gülgün Yılmaz, “Ayasuluk Kalesi ve St. Jean Anıtı Kazılarında Bulunan Seramikler," XVI. Ortaçă̆-Türk Dönemi Kazıları ve Sanat Tarihi Araştırmaları Sempozyumu Bildirileri (18-20 Ekim 2012) Bildiri Kitabı (Sivas: Cumhuriyet Üniversitesi Yayınları, 2014), 870, Res. 5(b). 
rosu kazıları Bizans dönemi sonrasında da seramik üretiminin devam ettiğini ortaya koymuştur. Aralarında yarı mamul örneklerinde olduğu tek renk sırlı ve çok renkli sgraffito seramikler renklerin kullanımı ve kompozisyon olarak İznik üretimlerine özgü gibi görünür ${ }^{60}$.

Amorium İç sur buluntuları arasındaki çok renkli sgraffito bezemeli çanak ve büyük tabak formlarının (T. 10-13) çoğunluğu, kaliteli yapı gösteren koyu ve açık yeşil tek renk sırlı seramiklerle benzerdir (T.1: 1, 2, 4, 5; T.3: 1-4). T.1, 2, 3, 4'de yer alan buluntularla T.10-12' dekiler arasında dokulu beyaz astar yapıları bakımından da benzerlik vardır. Burada izlenen formlar, üzerlerinde taşıdıkları bezeme kompozisyon ve motifleri yukarıda belirtilen birçok başka merkezden her iki türün tipik örnekleridir ${ }^{61}$. Analitik çalışması yapılmış yerel üretim olarak beliren Miletos'tan yarı mamul astarlı buluntular da örnekleri destekler ${ }^{62}$.

Şimdilik sayısal azlık ya da tipik özellikleri olmadığından analog imkanı taşımayan diğer tek renk sırlı Amorium buluntuları (T. 6-9), buluntu seviyelerindeki durumları itibarıyla diğer buluntularla çă̆daş olmalıdır.

Amorium'dan şimdilik az sayıda ele geçmiş turkuaz sırlı kaplara ilişkin de daha çok veriye ihtiyaç vardır (T.9: 1). İslami gelenek taşıyan bu tip kaplara ilişkin, Batı Anadolu'da yerleri tam olarak tanımlanamayan iki farklı yapı ile Ephesos; Pergamon üretimleri tespit edilmiştir. Analizlerle bunların kil karakterli astarlarının Bizans geleneğinde olduğunu ancak kurşun-alkali karışıma bakır oksit eklentisiyle yapılan opak sırın yenilik olduğu ortaya konmuştur ${ }^{63}$. İznik ${ }^{64}$ ve Sardis ${ }^{65}$ civarında da üretim

60 Boyalı Kazıma grubunda değerlendirilen İznik Tiyatrosu kazısı buluntularından bazı örnekler için bkz. Nurşen Özkul Fındık, İznik Roma Tiyatrosu Kazısı Buluntuları (1980-1995) Arasındaki Osmanlı Seramikleri (Ankara: T.C. Kültür Bakanlığı Yayınları, 2001), 92, Fot.83 (yarı mamul); 94, Fot.85-87; 95, Fot.90-93. İznik Çini Fırınları kazısından 14.-15. yüzyıl Bizans-Osmanlı Geçiş Dönemi olarak tarihlenmiş örnekler için bkz. Oktay Aslanapa, Şerare Yetkin ve Ara Altun, İznik Çini Fırınları Kazısı (1981-1988) II. Dönem (İstanbul: Tarihi Araştırmalar ve Dokümantasyon Merkezleri Kurma ve Geliştirme Vakfı, 1989), 57, kazı.env.no.1,3; 81, kazı env.no.82/2.

61 Büyük tabaklar/çanakların ağız kenar parçaları form olarak ortak bir durum gösterse de Ephesus/Ayasuluk'tan ele geçen yerel üretim örnekleri tondolarındaki kabartma halkalarla Amorium buluntularından farklıdır. Bkz. Yılmaz, "St. Jean (Aziz Yuhanna ) Kilisesi Atrium Kazılarında Bulunan Seramik Eserler," Kat.2.3; Kat. 2.4 Tire Kutu Han'dan Beylikler Dönemine tarihli bazı yeşil veya kavuniçimsi sarı sırlı kaideler cidar ve formu bakımından kendi arasında uyum gösterse de Amorium buluntularından ayrılır. Uçar ve Uçar, "Tire Kutu Han Kazısı Beylikler ve Osmanlı Dönemi Seramikleri,” 10, Tab.3.e,f,h.

62 Yarımamul Miletos buluntuları ve analizler için bkz. Sylvie Yona Waksman vd., "Moulded Wares Production in the Early Turkish/Beylik Period in Western Anatolia: A Case Study from Ephesus and Miletus," Journal of Archaeological Science: Reports 30 (2015), 667, form olarak Fig. 2 (980-55); yarı mamul olarak bezeme için 667, Fig. $2(982,56)$.

63 J. Burlot vd, "The Early Turkish Pottery Productions in Western Anatolia: Provenances, Contextualization and Techniques," Poster Presentation in XI th Congress AIECM3 on Medieval and Modern Period Mediterranean Ceramics (19-24 October), vol. I (Antalya: Koç Üniversitesi Vehbi Koç Ankara Araştırmaları Uygulama ve Araştırma Merkezi, 2018), 29.

64 Bazı örnekler için bkz. Özkul Fındık, İznik Roma Tiyatrosu Kazısı Buluntuları (1980-1995) Arasındaki Osmanll Seramikleri, 131, Fot. 124, 125; 134, Fot.138-140.

65 Scott ve Kamilli, "Late Byzantine Glazed Pottery from Sardis," 687. 
olduğu belirtilmektedir.

T.9: 2'de yer alan sıraltı boya tekniği ile firça darbeleriyle şekillenmiş bitkisel dekorlu parçalar Milet Tipi olarak tanınan kâselere aittir. Bezemede kobalttan ziyade açık mavimsi ton boya kullanılmıştır. Amorium Aşağı Şehir kazılarından da 14. yüzyıl ortasına tarihlenmiş Milet Tipi seramik parçaları yayınlanmış olmakla birlikte bunların dekor renkleri kobalt mavi olarak tanımlanmıștır ${ }^{66}$. Ancak bazılarının dıș yüzeylerinin yeşil sırlı olması burada tanıtılan kâse ile benzeşmektedir ${ }^{67}$. Az miktarda ele geçmiş Aşağı Şehir buluntularının İznik üretimi Milet Tipi olmadığı yazar tarafından belirlenmiştir ${ }^{68}$. Miletos, Ezine yakınlarında Akçaabat ${ }^{69}$, Pergamon, Aphrodisias ${ }^{70}$, Kütahya' $\mathrm{da}^{71}$ üretimi bilinen bu tipin coğrafi olarak Kütahya ile ilişkisi daha mümkün görülmekle birlikte daha fazla buluntuya ihtiyaç vardır ${ }^{72}$.

Amorium buluntusu astar boyamalı basit ağızlı (T.15: 1) ve tablalı tabak formları da (T.15: 2-3); tek renk, çok renk sırlı sgraffito kaplarla benzerdir. Tablalı ağız kenarı formu ve dekorasyon anlayışı bakımından yakınlık gösteren astar bezemeli bir tabak Aphrodisias'tan ele geçmiştir. Beylikler Dönemine tarihlendirilmiş tabakta, açık yeşil sır kullanıldığı ifade edilmekte olup ${ }^{73}$ Amorium T.15: 2'deki tabağın dudak üzeri açık yeşil renk ile sırlıdır. Erken Osmanlı döneminin İznik üretimleri de çok stilize olmamış bitkisel kompozisyonla kendini belli eder ${ }^{74}$.

Daha fazla kazı ve araştırma sonuçları neticesinde Beylikler Dönemi kapları büyüklükleri, cidar kalınlıkları, ağız kenarları ve bazı örneklerde kaide formlarında belirlenen özellikler daha iyi tanınmaya başlamışıır ${ }^{75}$. Çok renkli sgraffito seramikler-

66 Nurşen Özkul Fındık, "Turkish Glazed Pottery," Amorium Reports II: Research Papers and Technical Reports (Oxford: BAR International Series 1170, 2003), 109.

67 Özkul Findık, "Turkish Glazed Pottery,” 106, 111, 116, 207, P1.18, Kat.19, fig.VII/3.19.

68 Özkul Findık, "Turkish Glazed Pottery," 106.

69 John Walker Hayes, Excavations at Saraçhane in Istanbul, vol.II: The Pottery (Princeton: N.J., Princeton University Press, Washington: D.C: Dumbarton Oaks Research Library and Collection, 1992), 238, dipnot.4.

70 François, "Element Pour I'historie Ottomane d'Aphrodisias: la Vaiselle de Terre," 182.

71 Geniş bilgi için bkz. Faruk Şahin, "Kütahya Çini-Keramik Sanatı ve Tarihinin Yeni Buluntular Açısından Değerlendirilmesi," Sanat Tarihi Yıllı̆̆ 9/10 (1979-1980), 259-286; Lale Doğer, "Geçmişten Günümüze Kütahya Çiniciliği”, Antika\&Dekorasyon ve Sanat Dergisi 34 (1996), 152, Res.1.

72 Milet Tipi olarak tanınan kâselerin buluntu yerlerine ilişkin toplu bilgi için bkz. Niewöhner, "Der Bischofspalast von Milet," 253.

73 Buluntu için bkz. Öztaşkın, "Byzantine and Turkish Glazed Pottery Finds from Aphrodisias," 178, P1.7 (7).

74 İznik Tiyatro kazısından bazı örnekler için bkz. Özkul Fındık, İznik Roma Tiyatrosu Kazısı Buluntuları (19801995) Arasındaki Osmanlı Seramikleri, 30, Fot.1,2; 31, Fot.5,6. İznik Çini Fırınları kazısından 14.-15.yüzyı1 Bizans-Osmanlı Geçiş Dönemi olarak tarihlenmiş örnekler için bkz. Aslanapa, Yetkin ve Altun, İznik Çini Firınlarl Kazısı (1981-1988) II. Dönem, 81, kazı env.no.82/4; 146.

75 Bazı örnekler için bkz. Oluş Arık, "On the Ceramics Found in the Preliminary Phase of the Peçin excavation, Çanak," Arkeolojik Kazılarda Ele Geçen Geç Antik, Bizans, Selçuklu ve Osmanlı Seramiği ve Mimari Seramiği (Çanakkale, 1-3 Haziran 2005) Byzas 7 (İstanbul, Ege Yayınları, 2007) 528, T.9 (Beçin); Gök Gürhan, "1995-2009 Yı1ları Arasında Ortaya Çıkarılan Seramiklerin Değerlendirilmesi," 45-70, 58, Foto.4 (Beçin); Böhlendorf-Arslan, Die Glasierte Byzantinische Keramik aus der Turkei, Teil.III, Taf.110 (445); BöhlendorfArslan, "Die Beziehungen zwischen byzantinischer und emiratszeitlicher Keramik," 155, Abb.5-7; Spieser, 
de, Bizans geleneğinde ${ }^{76}$ kil kaynaklı astar ve kurşun esaslı sır kullanımı analizlerle belirlenmiş olsa $\mathrm{da}^{77}$, bazı esinlenmelerin dışında çoğu kez daha natüralist ve özenli bitkisel dekorlu İslami kapların çok stilize edilmiş yorumlarının tercih edildiği tarzları ile de kendilerini belli ederler.

\section{Sonuç}

Bu çalışmada incelenen çok renkli seramikler en fazla Amorium Yukarı Şehir, Karacahisar Kalesi ve yakın çevresi, Aphrodisias, Ephesos buluntuları ile form, bezeme tekniği ve kompozisyonları ile yakınlık gösterir. Amorium Yukarı Şehir buluntuları 14. yüzyılın 3. çeyreğine tarihlenmiştir. Aynı yerden tek renk yeşil sırlı buluntular için ise 13. yüzyılın ikinci yarısı-14. yüzyıl önerilmiştir.

14. yüzyıl Anadolu'sundaki karmaşık siyasi yapı içerisinde, arkeolojik verilerin tasnif ve yorumları kolay olmamakla birlikte yukarıda da belirtilen son çalışmalarla daha tanımlanabilir bir veri tabanı oluşmaya başlamıştır. Yeni önermeler ve buluntular arasında Amorium'da daha önce sağlam kontekstlerden bilinen Bizans seramiklerine rastlanılmamış olması da göz önüne alınarak çalışma alanında da Erken Türk/Beylikler Dönemi verilerinin belirdiği söylenebilir ${ }^{78}$.

Yukarı Şehir İç Sur GB Alanından aynı seviyelerde ele geçen tek renk (bezemelibezemesiz) seramikler ile çok renk sırlı sgraffito seramikleri 14. yüzyılın ortası-15. yüzyıl başına tarihlemek mümkün görülmektedir. Milet Tipi kâsenin benzerleri için de 14. yüzy1l ortas1-15. yüzyıl önermeleri olmakla birlikte daha net tarihlemeler için daha fazla veriye ihtiyaç vardır. Kazının seramik dışında diğer buluntularının da değerlendirmeye katılması ile daha dar bir tarih aralığ 1 öngörülebilir. Sırlı seramik buluntuların çoğunu, bölgedeki Selçuklu Egemenliğinden Erken Osmanlı Egemenliğine geçiş sürecinin Geç Ortaçağ buluntuları olarak tanımlamak mümkündür.

Die Byzantinische Keramik Aus der Stadtgrabung von Pergamon, Taf. 53 (507, 509, 510).

76 Burlott vd., "The Early Turkish Pottery Productions in Western Anatolia: Provenances, Contextualization and Techniques," 429.

77 Burlott vd., "The Early Turkish Pottery Productions in Western Anatolia: Provenances, Contextualization and Techniques," 429.

78 Amorium kazılarından Bizans seramikleri için bkz. Beate Böhlendorf-Arslan, "The Pottery from Destruction Contexts in the Enclosure," Amorium Reports II: Research Papers and Technical Reports. (Oxford: BAR International Series 1170, 2003), 153-179; Beate Böhlendorf-Arslan, "Stratifield Byzantine Pottery from the City Wall in Southwestern Sector of Amorium," 273-294; Beate Böhlendorf-Arslan "Die Mittelbyzantinische Keramik aus Amorium," Byzanz-das Römerreich im Mittelalter, Teil 2.1. (Mainz: Verlag des Römisch-Germanischen Zentralmuseums, 2010), 345-371. Selçuklu ve Osmanlı dönemlerine ait ilk tespitler için bkz. Chris Lightfoot, "Amorium-Hisarcık'ın Selçuklu ve Osmanlı Dönemlerine Ait Yerleşim ve Arkeolojisi”, Sanat Tarihi Dergisi 9/9 (1998), 75-84. 
Hakem Değerlendirmesi: Dış bağımsız.

Çıkar Çatışması: Yazarlar çıkar çatışması bildirmemiştir.

Finansal Destek: Yazarlar bu çalışma için finansal destek almadığını beyan etmiştir.

Teşekkür: Buluntuların çalışılması için izin veren Amorium kazı başkanı Prof. Dr. Zeliha Demirel Gökalp'e, bize tüm olanakları sağlayan ve İç Sur alanı kazılarını gerçekleştiren Dr. Öğr. Üyesi Hasan Yılmazyaşar'a, seramiklerin çizim ve fotoğraf çekimlerini yapan Karacahisar kazısı ekip üyeleri Nurten Kambur, Songül Akelma, Aleyna Bayraktar, Özcan Yamaç ve Mahmut İçer'e teşekkür ederiz.

Peer-review: Externally peer-reviewed.

Conflict of Interest: The authors have no conflict of interest to declare.

Grant Support: The authors declared that this study has received no financial support.

Acknowledgement: We would like to thank The head of the Amorium excavation, which allowed the study of the finds, Dr. To Zeliha Demirel Gokalp, Lecturer Hasan Yılmazyaşar, who provided us with all the possibilities and made the Inner Wall area excavations, Karacahisar excavation team members Nurten Kambur, Songül Akelma, Aleyna Bayraktar, Özcan Yamaç and Mahmut İçer.

\section{Kaynakça/References}

Arık, Oluş. "On the Ceramics Found in the Preliminary Phase of the Peçin Excavation." Çanak Arkeolojik Kazılarda Ele Geçen Geç Antik, Bizans, Selçuklu ve Osmanl Seramiği ve Mimari Seramiği Uluslararası Seramik Sempozyumu (1-3 Haziran 2005, Çanakkale) Bildiri Kitabl: Byzas 7. İstanbul: Ege Yayınları, 2007, 523-530.

Arthur, Paul. Bizans ve Türk Dönemi'nde Hierapolis (Pamukkale). İstanbul: Ege Yayınları, 2006.

Aslanapa, Oktay, Şerare Yetkin ve Ara Altun. İznik Çini Fırınları Kazısı (1981-1988) II. Dönem. İstanbul: Tarihi Araştırmalar ve Dokümantasyon Merkezleri Kurma ve Geliştirme Vakfi, 1989.

Bakırer, Ömür. "The Medieval Pottery and Baked Clay Objects." Korucutepe, Final Report on the Excavation of the Universities of Chicago. 3. cilt. Amsterdam: Nort-Holland Publishing Company, 1980, 189-249.

Böhlendorf-Arslan, Beate. "Die Beziehungen Zwischen Byzantinischer und Emiratszeitlicher Keramik.” Ortaçağ 'da Anadolu Prof. Dr. Aynur Durukan'a Armağan. Ankara: Hacettepe Üniversitesi Edebiyat Fakültesi Yayınları, 2002, 135-156.

Böhlendorf-Arslan, Beate. The Pottery from Destruction Contexts in the Enclosure. Oxford: BAR International Series 1170, 2003, 153-179.

Böhlendorf-Arslan, Beate. Die Glasierte Byzantinische Keramik aus der Turkei. İstanbul: Ege Yayınları, 2004.

Böhlendorf-Arslan, Beate. "Stratifield Byzantine Pottery from the City Wall in the Southwestern Sector of Amorium." Çanak Arkeolojik Kazılarda Ele Geçen Geç Antik, Bizans, Selçuklu ve Osmanlı Seramiği ve Mimari Seramiği Uluslararası Seramik Sempozyumu (1-3 Haziran 2005, Çanakkale) Bildiri Kitabı: Byzas 7. İstanbul: Ege Yayınları, 2007, 273-294.

Böhlendorf-Arslan, Beate. "Die Mittelbyzantinische Keramik aus Amorium.” Byzanz-das Römerreich im Mittelalter. Teil 2.1. Mainz: Verlag des Römisch-Germanischen Zentralmuseums, 2010, 345-371.

Burlot, J., Yona Waksman, A. Bouquillon, Joanita Vroom, Beate Böhlendorf-Arslan, Sarah Japp ve I. Teslenko. "The Early Turkish Pottery Productions in Western Anatolia: Provenances, Contex- 
tualization and Techniques." Poster Presentation in XIth Congress AIECM3 on Medieval and Modern Period Mediterranean Ceramics (19-24 October 2015, Antalya). Antalya: Koç Üniversitesi Vehbi Koç Ankara Araştırmaları Uygulama ve Araştırma Merkezi, 2018, 427-430.

Bursal1, Muradiye. "Eskişehir Karacahisar Kalesi Sgraffito Dekorlu Ortaçağ Seramikleri.” Yüksek Lisans Tezi, Eskişehir Anadolu Üniversitesi, 2007.

Crane, Howard G. "Preliminary Observations on the Glazed Pottery of the Turkish of the Period from Sardis." Bulletin of the American Schools of Oriental Research 228 (1977): 47-59.

D'amico, Erica. "Byzantine Finewares in Italy (10th to 14th Centuries AD): Social and Economic Contexts in the Mediterranean World.” Doktora Tezi, Durham University, 2011.

Demirel Gökalp, Zeliha, Ayşe Ceren Erel, Nikos Tsivikis ve Hasan Yılmazyaşar. "2014 y1lı Amorium Kazısı.” 37. Kazı Sonuçları Toplantısı. 3. cilt. Ankara: T.C. Kültür ve Turizm Bakanlığı Yayınları, 2016, 199-214.

Demirel Gökalp, Zeliha, Ayşe Ceren Erel, Nikos Tsivikis ve Selda Yazıcı Uygun. "2015 yılı Amorium Kazısı.” 38. Kazı Sonuçları Toplantısı. 3. cilt. Ankara: T.C. Kültür ve Turizm Bakanlığı Yayınları, 2017, 451-460.

Demirel Gökalp, Zeliha, Ayşe Ceren Erel ve Hasan Yılmazyaşar. “2016 yılı Amorium Kazısı.” 39. Kazı Sonuçları Toplantısı. 2. cilt. Ankara: T.C. Kültür ve Turizm Bakanlığı Yayınları, 2018, 557-570.

Demirel Gökalp, Zeliha, Ayşe Ceren Erel, Nikos Tsivikis ve Hasan Yılmazyaşar. "Amorium Kazıları 2017.” 40. Kazı Sonuçları Toplantısı. 3. cilt. Ankara: T.C. Kültür ve Turizm Bakanlığı Yayınları, 2019, 713-725.

Demirel Gökalp, Zeliha, Ayşe Ceren Erel, Nikos Tsivikis, Hasan Yılmazyaşar ve Mehmet Kurt. "2018 Yılı Amorium Kazıları.” 41. Kazı Sonuçları Toplantısı. 4. cilt. Ankara: T.C. Kültür ve Turizm Bakanlığı Yayınları, 2019, 567-577.

Doğer, Lale. "Geçmişten Günümüze Kütahya Çiniciliği.” Antika \& Dekorasyon ve Sanat Dergisi 34 (1996): 152-156.

Doğer, Lale. “Anaia-Kuşadası Kadıkalesi Kazısı 2002 Yılı Bizans Dönemi Seramik Buluntuların Ön Değerlendirmesi.” Sanat Tarihi Dergisi, Aydoğan Demir'e Armağan 13/1 (2004): 1-31.

Doğer, Lale. Late Byzantine And Ottoman Pottery From Nif-Olympus. Oxford: BAR International Series 2750, 2015, 57-70.

François, Veronique. Element Pour I'historie Ottomane d'Aphrodisias: la Vaiselle de Terre. Anatolia Antigua 9 (2001): 147-190.

Gök Gürhan, Sevinç. "Balat İlyas Bey Külliyesi Kazısında Ortaya Çıkarılan Seramiklerin Değerlendirilmesi (2007-2008).” 8. Ortaçağ-Türk Dönemi Kazıları ve Sanat Tarihi Araştırmaları Sempozyumu (14-16 Ekim 2009, Denizli) Bildiri Kitabı. Denizli: Pamukkale Üniversitesi Fen-Edebiyat Fakültesi Sanat Tarihi Bölümü Yayınları, 2010, 291-305.

Gök Gürhan, Sevinç. "Beylikler Dönemine Ait Sgraffito Teknikli ve Tek Renk Sırlı Kaplar (Manisa Gülgün Hatun Hamamı Buluntuları).” Sanat Tarihi Dergisi 17/2 (2010): 59-83.

Gök Gürhan, Sevinç. Bir Seramik Definesinin Öyküsü, Saruhan Beyliği’nin Mirası: Manisa Gülgün Hatun Hamamı Seramikleri. Manisa: Manisa Belediyesi Yayınları, 2011.

Gök Gürhan, Sevinç. “1995-2009 Yılları Arasında Ortaya Çıkarılan Seramiklerin Değerlendirilmesi." Sanat Tarihi Dergisi 18/2 (2011): 45-70.

Hayes, John Walker. Excavations at Saraçhane in Istanbul, vol. II: The Pottery. Princeton: N.J., Princeton University Press, Washington: D.C: Dumbarton Oaks Research Library and Collection, 
1992.

Lightfoot, Chris. “Amorium-Hisarcık'ın Selçuklu ve Osmanlı Dönemlerine Ait Yerleşim ve Arkeolojisi." Sanat Tarihi Dergisi 9/9 (1998): 75-84.

Mercangöz, Zeynep ve Doğer, Lale. "Kuşadası, Kadıkalesi/Anaia Bizans Sırlı Seramikleri.” I. Arkeometri Çalıştayl, Türkiye Arkeolojisi'nde Seramik ve Arkeometrik Çalışmalar, Prof. Dr. Ufuk Esin Anısına (7-9 Mayıs 2009). Ankara: Orta Doğu Teknik Üniversitesi Yayınları, 2009, 83-101.

Mercangöz, Zeynep, Zafer Derin ve Lale Doğer. “Kemalpaşa, Laskarisler Sarayı.” Ege Üniversitesi Arkeoloji Kazıları. İzmir: Ege Üniversitesi Yayınları, 2012, 440-450.

Niewöhner, Philipp. “Der Bischofspalast von Milet.” Archaologischer Anzeiger 2015/2 (2016): $181-273$

Özkul Fındık, Nurşen. İznik Roma Tiyatrosu Kazısı Buluntuları (1980-1995) Arasındaki Osmanlı Seramikleri. Ankara: T.C. Kültür Bakanlığı Yayınları, 2001.

Özkul Fındık, Nurşen. “Turkish Glazed Pottery.” Amorium Reports II: Research Papers and Technical Reports. Oxford: BAR International Series 1170, 2003, 105-211.

Özkul Fındık, Nurşen. “Artuklu-Eyyubi Dönemlerinde Hasankeyf’te Seramik Atölyeleri ve Üretimleri.” Hacettepe Üniversitesi Edebiyat Fakültesi Dergisi 30/2 (2013): 43-58.

Öztaşkın, Muradiye. "Eskişehir Karacahisar Kalesi Ortaçağ Seramiklerinden Bir Grup: Yeşil ve Erguvan Lekeli Seramikleri.” 8. Ortaçă̆ ve Türk Dönemi Kazıları ve Sanat Tarihi Araştırmaları Sempozyum (14-16 Ekim 2009) Bildiri Kitabı. Denizli: Pamukkale Üniversitesi Fen-Edebiyat Fakültesi Sanat Tarihi Bölümü Yayınları, 2010, 524-536.

Öztaşkın, Muradiye. "Byzantine and Turkish Glazed Pottery Finds from Aphrodisias.” Поливная Керамика Средиземноморья И Причерноморья X-Хvиı Вв. 2. cilt. Ed. С. Г. Бочарова, В. Франсуа ve А. Г. Ситдикова. Kazan- Kishinev: Издательство «Stratum plus» P.Р.,Университет «Высшая антропологическая школа», 2017, 165-188.

Papanikola-Bakirtzi, Demetra., F. N. Mavrikiou ve Ch. Bakirtzi. Byzantine Glazed Pottery in the Benaki Museum. Athens: The Museum, 1999.

Polat, Turgay. "Milet İşi Seramiklerde Form Tipolojisi Üzerine Bir Deneme.” Sanat Tarihi Dergisi 25/2 (2016): 213-247.

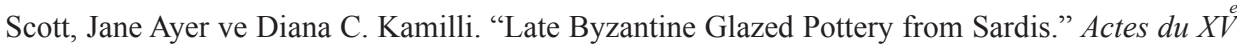
Congrès International d'Études Byzantines XV (Septembre 1976, Athenes), II. Athenes: Art et Archéologie B, 1981, 679-696.

Spieser, Jean Michel. Die Byzantinische Keramik Aus der Stadtgrabung von Pergamon. Berlin: Walter de Gruyter, 1996.

Şahin, Faruk. "Kütahya Çini-Keramik Sanatı ve Tarihinin Yeni Buluntular Açısından Değerlendirilmesi.” Sanat Tarihi Ylllı̆̆ 9-10 (1979-1980): 259-273.

Uçar, Hasan ve Uçar, Aygül. "Tire Kutu Han Kazısı Beylikler ve Osmanlı Dönemi Seramikleri." Sanat Tarihi Dergisi 27/1 (2018): 1-31.

Vroom, Joanita. "Medieval Pottery from the Artemision in Ephesos: Imports and Locally Produced Wares." Spatantike und Mittelalterliche Keramik aus Ephesus. Wien: Österreichische Akademie der Wissenschaften, 2005, 17-49.

Vroom, Joanita ve Ebru Find1k. "The Pottery Finds.” Die Türbe im Artemision, Österreichisches Archäologisches Institut Sonderschriften 53. Wien: Gesamtherstellung. Holzhausen Druck 
GmbH, 2015, 205-292

Vroom, Joanita. "Bright Finds, Big City: Medieval Ceramics from Old and Recent Excavations in Ephesus (Turkey).” XIth Congress AIECM3 on Medieval and Modern Period Mediterranean Ceramics, Proceedings (19-24 October 2015, Antalya). I. cilt. Ankara: Koç University Vehbi Koç Ankara Araştırmaları Uygulama ve Araştırma Merkezi, 2018, 383-396.

Waksman, Sylvie Yona ve Jean Michel Spieser, "Byzantine Ceramics Excavated in Pergamon: Archaeological Classification and Characterization of the Local and Imported Productions by PIXE and INAA Elemental Analysis,Mineralogy and Petrography." Materials Analysis of Byzantine Pottery. Washington: Dumbarton Oaks Research Library and Collection, 1997, 105-133.

Waksman, Sylvie Yona. "The Identification and Diffusion of Anaia's Ceramic Products: A Preliminary Approach Using Chemical Analysis.” Byzantine Craftsmen-Latin Patrons, Reflections from the Anaian Commercial Production in the Light of the Excavations at Kadikalesi nearby Kuşadası. İstanbul: Ege Yayınları, 2013, 101-112.

Waksman, Sylvie Yona ve M. M. Carytsiotis. "Medieval Ceramics from the Türbe: An Archaeometric Viewpoint." Die Türbe im Artemision Ein Frühosmanischer Grabbau in Ayasuluk/Selçuk und Sein Kulturhistorisches Umfeld. Wien: Österreichisches Archäologisches Institut, 2015, 293-312.

Waksman, Sylvie Yona, J. Burlot, Beate Böhlendorf-Arslan ve Joanita Wroom. "Moulded Wares Production in the Early Turkish/Beylik period in Western Anatolia: A Case Study from Ephesus and Miletus." Journal of Archaeological Science Reports 30 (2015): 1-11.

Y1lmaz, Gülgün. Edirne Müzesi Osmanlı Seramikleri, Zindanaltı Buluntuları. Edirne: Trakya Kalkınma Ajans1, 2012.

Yılmaz, Gülgün. "Ayasuluk Kalesi ve St. Jean Anıtı Kazılarında Bulunan Seramikler.” XVI. Ortaçağ-Türk Dönemi Kazıları ve Sanat Tarihi Araştırmaları Sempozyumu (18-20 Ekim 2012) Bildiri Kitabı. Sivas: Cumhuriyet Üniversitesi Yayınlar1, 2014, 863-871.

Y1lmaz, Gülgün. "St. Jean (Aziz Yuhanna) Kilisesi Atrium Kazılarında Bulunan Seramik Eserler.” Mustafa Büyükkolancı'ya Armağan Kitabı. İstanbul: Ege Yayınları, 2015, 766-780. 


\section{Ek.1 /Mal Gruplarına göre buluntu uygunluk durumu}

Yukarı Şehir İS Alanı 1 No.lu Açma +976.21 m./T.7:2 (AMR18.707 tek renk açık sarı sırlı); T.16:3 (yeşil lekeli)

Yukarı Şehir İS Alanı 1 No.lu Açma +975.31 m./İS T.5:1-3 (AMR18.702, AMR18.703, AMR 18.704 tek renk açık yeşil sırlı )

Yukarı Şehir İS Alanı 1 No.lu Açma +974.08-972.78m./T.6:5 (AMR17.76 iç tek renk sarımsı yeşil sirli)

Yukarı Şehir İS Alanı 2 No.lu Açma +977.10-976.44m./T.10:3 (AMR17.127 yeşil ve erguvan lekeli); T.16:5 (AMR17.130 sirs1z)

Yukarı Şehir İS Alanı 2 No.lu Sondaj +976.70-976.00m./T.8:4 (AMR17.201 kavuniçimsi sarı renk sirli)

Yukarı Şehir İS Alanı 3 No.lu Açma +976.94-976.43m./T.1:1,3 (AMR17.167, AMR17.182) (tek renk koyu yeşil sırlı) ; T.6:4,7 (AMR17.224, AMR17 (tek renk sarımsı yeşil- yeşil sırlı); T.11:4 (AMR17.171 yeşil ve erguvan lekeli)

Yukarı Şehir İS Alanı 3 No.lu Sondaj +976.68-976.49m./T.4:2 (AMR17.74 tek renk koyu yeşil sırlı)

Yukarı Şehir İS Alanı 4 No.lu Açma doğu /T.1:2 (AMR18.701 tek renk koyu yeşil sırlı)

Yukarı Şehir İS Alanı 4 No.lu Sondaj +975.45-981.62m./T.6:3 (AMR17.218 tek renk sarımsı yeşil sirl1)

Yukarı Şehir İS Alanı 4 No.lu Sondaj +978.45-976.73m./T.3:2 (AMR17); T.4:7(AMR 17.116) (tek renk koyu yeşil sırl1)

Yukarı Şehir İS Alanı 5 No.lu Açma +978.65-778.25m./T.6:2 (AMR17.366 tek renk sarımsı yeşil sirl1)

Yukarı Şehir İS Alanı 5 No.lu Açma +977.81-777.28m./T.2:1-4 (AMR18.711, AMR18.710, AMR18.606, AMR18.592 tek renk koyu yeşil)

Yukarı Șehir İS Alanı 5 No.lu Açma +977.45m./T.8:2 (AMR18.708 kavuniçimsi sarı sırl1); T.15:1 (AMR18.709 astar bezemeli )

Yukarı Şehir İS Alanı 5 No.lu Açma +977.81-777.72m./T.11:5 (AMR18.521 yeşil ve erguvan lekeli)

Yukarı Şehir İS Alanı 6 No.lu Açma +976.43m./T.7:1 (AMR18.480 tek renk açık sarı sırlı ); T.13: 3 (AMR18.579 yeşil ve erguvan lekeli)

Yukarı Şehir İS Alanı 7 No.lu Açma +976.88m./T.3:1 (AMR18.199 tek renk koyu yeşil sırlı); T.9:1 AMR18.713 (turkuaz sirl1)

Yukarı Şehir İS Alanı 7 No.lu Açma +976.28m./T.1:5 (AMR18.245); T.2:5 (AMR18.712) (tek renk koyu yeşil sırl1); T.10:4 (AMR18.248 yeşil ve erguvan lekeli)

Yukarı Şehir İS Alanı 9 No.lu Açma +978.57m. doğu kod/T.15:4,5,6 (AMR18.714, AMR 18.715 astar bezeli); T.12:2,3 (AMR18.720, AMR18.723 yeşil ve erguvan lekeli)

Yukarı Şehir İS Alanı 9 No.lu Açma +978.51m. batı kod/T.1:4 (AMR18.718 tek renk koyu yeşil sırl1); T.11: 8 ( AMR 18.722 yeşil ve erguvan lekeli)

Yukarı Şehir İS Alanı 4 no.lu sondaj +978.45-976.73m./T.2:3 (AMR17.115 tek renk koyu yeşil sırlı) Yukarı Şehir İS Alanı 9 batı kod/T.8:5 (AMR18.719 kavuniçimsi sarı sırlı)

Yukarı Şehir İS Alanı 10 No.lu Açma +977.76m./T.6:6 (AMR18.410 tek renk yeşilimsi sarı-yeşil sırl1) T.11:3,6 (AMR18.425, AMR18.507;T.13:1 (AMR18.202 yeşil ve erguvan lekeli); T.16:1 (AMR18.199 tek renk sirl1) 
Yukarı Şehir İS Alanı 11 No.lu Açma +976.63m./T.1:6,7 (AMR18.743, AMR18.733; T.3: 4 5,6,7,8 (AMR18.728, AMR18.742, AMR18.731, AMR18.744, AMR18.732); T.4:6,8 (AMR18.342, AMR18.197 (tek renk koyu yeşil sırl1); T.6:6 (AMR18.410 tek renk sarımsı yeşil); T.7:3 (AMR18.740 tek renk açık sarı sırlı ); T.8:3 (AMR18.730 kavuniçimsi sarı sırl1); T.9.2 (AMR18.735 Milet Tipi?); T.10:1,2 (AMR18.737, AMR18.739); T.11:2 (AMR18.734); T.12: 1,5 (AMR18.738, AMR18.747); T.13:4 (AMR18.181, T.14:1 (AMR18.727) (yeşil ve erguvan lekeli)

Yukarı Şehir İS Alanı 12 No.lu Açma +977.70m./T.4:1,4,5 (AMR18.467, AMR18.418, AMR18.433) tek renk yeşil sırl1; T.10:5 (AMR18.470); T.11:1 (AMR18.424); T.13:2, 5 (AMR18.576, AMR18.518; T.14:2,3 (AMR18.429, AMR18.475) yeşil ve erguvan lekeli)

Yukarı Şehir İS Alanı tanımsız T.2:6 (AMR18.476 tek renk yeşil sırlı); T.15:2,3 (AMR18.184 astar bezeli); T.12:6 (AMR18.747 yeşil ve erguvan lekeli); T.16:2 (AMR18.478 tek renk sırl1) T.16:2 (AMR18.746 çok renkli sgraffito?)

\section{Ek.2/ Tablo içeriğinde buluntu alanları}

T.1:1,3 (AMR17.167, AMR17.182) 3 No.lu Açma +976.94-976.43m.

T.1:2 (AMR18.701) 4 No.lu Açma doğu

T.1:4 (AMR18.718) 9 No.lu Açma +978.51m. batı kod

T.1:5 (AMR18.245) 7 No.lu Açma +976.2m.

T.1:6,7 (AMR18.743, AMR18.733 11 No.lu Açma +976.63m.

T.2:1-4 (AMR18.711, AMR18.710, AMR18.606, AMR18.592 5 No.lu Açma +977.81- 777.28m.

T.2:3 (AMR17.115) 4 no.lu sondaj +978.45-976.73m.

T.2:5 (AMR18.712) 7 No.lu Açma +976.28m.

T.2:6 ( AMR18.476) Alanı tanımsız

T.3:1 (AMR18.199) 7 No.lu Açma +976.88m.

T. 3:2 (AMR17) 4 No.lu Sondaj +978.45-976.73m.

T.4:1,4,5 (AMR18.467, AMR 18.418, AMR 18.433) 12 No.lu Açma +977.70m.

T.4: 6, 8 (AMR18.342, AMR 18.197) 11 No.lu Açma +976. 63m.

T.4:7 (AMR17.116) 4 No.lu Açma +978.45-976.73m.

T.4:2 (AMR 17.74) 3 No.lu Açma +976. 68-976.49m.

T.5:1-3 (AMR18.702, AMR.18.703, AMR 18.704) 1 No.lu Açma +975.31m.

T.6:2 (AMR17.366) 5 No.lu Açma +978.65-778.25m.

T.6:3 ( AMR17.218) 4 No.lu Açma +975.45-981.62m.

T.6:4,7 (AMR17.224, AMR17) 3 No.lu Açma +976. 94-976.43m.

T.6:5 (AMR17.76) 1 No.lu Açma +974. 08-972.78m.

T.6:6 ( AMR18.410) 10 No.lu Açma +977.76m.

T.6:6 (AMR18.410) 11 No.lu Açma +976.63m.

T.7:1 (AMR18.480) 6 No.lu Açma +976.43m.

T.7: 2 (AMR18-707 1 No.lu Açma +976.21 m.

T.11:3, 6 ( AMR 18.425, AMR 18.507) 10 No.lu Açma +977.76m. 
T.11:5 (AMR18.521) 5 No.lu Açma +977.81-777.72m.

T.11:8 (AMR18.722) 9 No.lu Açma +978.51m. batı kod

T.7:3 (AMR18.740) 11 No.lu Açma +976.63m.

T.8:2 (AMR18.708) 5 No.lu Açma +977.45m.

T.8:3 (AMR18.730) 11 No.lu Açma +976.63m.

T.8:4 (AMR17.201 2 No.lu Açma +976 70-976.00m.

T.8:5 (AMR18.719) 9 batı kod

T.9:1 (AMR18.713) 7 No.lu Açma +976.8m.

T.9.2 (AMR18.735) 11 No.lu Açma +976.63m.

T.10:1,2 (AMR18.737, AMR 18.739) 11 No.lu Açma +976. 63m.

T.10:3 (AMR 17.127 2 No.lu Açma +977. 10-976.44m.

T.10:4 (AMR18.248) 7 No.lu Açma +976.28m

T.10:5 (AMR18.470) 12 No.lu Açma +977.70m.

T.11:1 (AMR18.424) 12 No.lu Açma +977.70m.

T.11:2 (AMR18.734) 11 No.lu Açma +976.63m.

T.11:4 (AMR17.171 3 No.lu Açma +976.94-+976.43m.

T.12:1,5 (AMR18.738, AMR18.747) 11 No.lu Açma +976.63m.

T.12:2,3 (AMR18.720, AMR18.723) 9 No.lu Açma +978.57m. doğu kod

T.12:6 (AMR18.747) Alanı tanımsız

T.13:1 (AMR18.202) $\mathbf{1 0}$ No.lu Açma +977.76m.

T.13:3 (AMR18.579) 6 No.lu Açma +976.43m.

T.13:2, 5 (AMR18.576, AMR 18.518) 12 No.lu Açma +977.70m.

T.13:4 (AMR18.181) 11 No.lu Açma +976.63m.

T.14:1 (AMR18.727) 11 No.lu Açma +976. 63m.

T.14:2,3 (AMR18.429, AMR 18.475) 12 No.lu Açma +977.70m.

T.15:1 (AMR18.709) 5 No.lu Açma +977.45m.

T. 15:2,3 (AMR18.184) Alanı tanımsız

T.15:4,5,6 (AMR18.714, AMR 18.715) 9 No.lu Açma +978.57m. doğu kod

T.16:1 (AMR18.199) $\mathbf{1 0}$ No.lu Açma +977.76m.

T.16:2 (AMR18.478) 5 No.lu Açma +977.45m.

T.16:3 (AMR18.707) 1 No.lu Açma +976.21m

T.16:2,4 (AMR18.478, AMR 18.746) Alanı tanımsız

T.16:5 (AMR18.729) 11 No.lu Açma +976.63m. 